\title{
Expression Profiles of Genes Encoded by the Supernumerary Chromosome Controlling AM-Toxin Biosynthesis and Pathogenicity in the Apple Pathotype of Alternaria alternata
}

\author{
Yoshiaki Harimoto, ${ }^{1}$ Rieko Hatta, ${ }^{1}$ Motoichiro Kodama, ${ }^{2}$ Mikihiro Yamamoto, ${ }^{3}$ Hiroshi Otani, ${ }^{2}$ and \\ Takashi Tsuge ${ }^{1}$ \\ ${ }^{1}$ Graduate School of Bioagricultural Sciences, Nagoya University, Chikusa, Nagoya 464-8601, Japan; ${ }^{2}$ Faculty of Agriculture, \\ Tottori University, Tottori 680-8553, Japan; ${ }^{3}$ College of Agriculture, Okayama University, Okayama 700-8530, Japan
}

Received 26 February 2007. Accepted 4 September 2007.

\begin{abstract}
The apple pathotype of Alternaria alternata produces hostspecific AM-toxin and causes Alternaria blotch of apple. Previously, we cloned two genes, $A M T 1$ and $A M T 2$, required for AM-toxin biosynthesis and found that these genes are encoded by small, supernumerary chromosomes of $<1.8 \mathrm{Mb}$ in the apple pathotype strains. Here, we performed expressed sequence tag analysis of the 1.4-Mb chromosome encoding $A M T$ genes in strain IFO8984. A cDNA library was constructed using RNA from AM-toxinproducing cultures. A total of 40,980 clones were screened with the 1.4-Mb chromosome probe, and 196 clones encoded by the chromosome were isolated. Sequence analyses of these clones identified 80 unigenes, including $A M T 1$ and $A M T 2$, and revealed that the functions of $43(54 \%)$ genes are unknown. The expression levels of the 80 genes in AMtoxin-producing and nonproducing cultures were analyzed by real-time quantitative polymerase chain reaction (PCR). Most of the genes were found to be expressed in both cultures at markedly lower levels than the translation elongation factor 1- $\alpha$ gene used as an internal control. Comparison of the expression levels of these genes between two cultures showed that 21 genes, including $A M T 1$ and $A M T 2$, were upregulated ( $>10$-fold) in AM-toxin-producing cultures. Two of the upregulated genes were newly identified to be involved in AM-toxin biosynthesis by the gene disruption experiments and were named $A M T 3$ and AMT4. Thus, the genes upregulated in AM-toxin-producing cultures contain ideal candidates for novel AM-toxin biosynthetic genes.
\end{abstract}

Additional keywords: host-specific toxin.

Alternaria alternata is one of the most cosmopolitan fungal species and generally is saprophytic (Rotem 1994; Thomma 2003). However, A. alternata contains seven variants (patho-

Corresponding author: T. Tsuge; Telephone: +81-52-789-4030; Fax: +8152-789-4030; E-mail: ttsuge @ agr.nagoya-u.ac.jp

Nucleotide sequences are available in the DDBJ, EMBL, and GenBank databases as accession numbers CI999779 to CI999919 for expressed sequence tag clones, AB359463 for AMT3, and AB359464 for AMT4.

The Spotlight logo represents articles that, in the opinion of the senior editor and editor-in-chief, are of special interest to a broad readership. types), which produce host-specific toxins and cause necrotic diseases in different plants (Kohmoto et al. 1995; Thomma 2003). Host-specific toxins produced by A. alternata are lowmolecular weight secondary metabolites of diverse structure and are critical determinants of host-specific pathogenicity or virulence (Kohmoto et al. 1995; Markham and Hille 2001; Thomma 2003; Wolpert et al. 2002). These pathotypes are fascinating cases for studying intraspecific variation and evolution of pathogenicity in plant pathogenic fungi (Kohmoto et al. 1995; Thomma 2003).

The apple pathotype of $A$. alternata produces cyclic depsipeptide AM-toxin (Fig. 1) (Okuno et al. 1974; Ueno et al. 1977) and causes Alternaria blotch, a disease of worldwide importance, on apple cultivars susceptible to AM-toxin (Filajdić and Sutton 1991; Sawamura 1990). We previously identified two AM-toxin biosynthetic genes, $A M T 1$ and $A M T 2$, required for AM-toxin biosynthesis (Ito et al. 2004; Johnson et al. 2000). AMT1 (previously named $A M T$ ) encodes a $479-\mathrm{kDa}$ nonribosomal peptide synthetase containing four catalytic domains responsible for the activation of each residue in AM-toxin (Fig. 1) (Johnson et al. 2000). AMT2 probably encodes an aldo-keto reductase required for biosynthesis of 2-hydroxy-isovaleric acid that is one of the AM-toxin residues (Fig. 1) (Ito et al. 2004).

Using pulsed-field gel electrophoresis (PFGE), Akamatsu and associates (1999) observed that strains from A. alternata pathotypes have small chromosomes of $<1.9 \mathrm{Mb}$ but that nonpathogenic strains do not have such small chromosomes. They also found that AMT1 resides on a small chromosome of 1.1 to $1.8 \mathrm{Mb}$ in the apple pathotype strains. Small chromosomes of several fungi have been identified as supernumerary (dispensable) chromosomes (Covert 1998). The function of supernumerary chromosomes in most species is still cryptic. However, in the pea pathogen Nectria haematococca, the 1.6-Mb supernumerary chromosomes have been characterized as encoding functional genes for phytoalexin detoxification as well as other virulence determinants (Covert et al. 1996; Han et al. 2001; Kistler et al. 1996; Miao et al. 1991; VanEtten et al. 1998; Wasmann and VanEtten 1996). Inherent instability of the supernumerary chromosomes does not affect growth but does affect virulence on host plants (Kistler et al. 1996; Miao et al. 1991; VanEtten et al. 1998; Wasmann and VanEtten 1996). Fungal supernumerary chromosomes, which are not required for growth but do confer an advantage for colonizing certain ecological niches, have been termed conditionally dispensable (CD) chromosomes (Covert 1998). 
Johnson and associates (2001) found a nonpathogenic mutant that lacks AM-toxin from laboratory stocks of the apple pathotype strains. An original strain of this mutant was found to have a 1.1-Mb chromosome encoding AMT1 and to be pathogenic to susceptible apple cultivars by producing AM-toxin. The mutant lacking AM-toxin, however, lacked the 1.1-Mb chromosome. This mutant normally grew and sporulated on media. Thus, Johnson and associates (2001) proposed that the 1.1-Mb chromosome is probably a CD chromosome controlling AM-toxin biosynthesis and pathogenicity of this strain.

Host-specific toxin biosynthetic genes have been isolated from five pathotypes (apple, Japanese pear, strawberry, tangerine, and tomato) of A. alternata (Akagi et al. 2005; Hatta et al. 2002; Ito et al. 2004; Johnson et al. 2000; Masunaka et al. 2000; Ruswandi et al. 2005; Tanaka and Tsuge 2000; Tanaka et al. 1999; Yamagishi et al. 2006). Toxin biosynthetic genes appeared to be clustered on small chromosomes of $<2.0 \mathrm{Mb}$ in most strains of these pathotypes tested (Akagi et al. 2005; Hatta et al. 2002, 2006; Ito et al. 2004; Johnson et al. 2001; Masunaka et al. 2005). We isolated mutants lacking small chromosomes encoding toxin biosynthetic genes from the strawberry and tomato pathotypes and found that these chromosomes are also CD chromosomes (Akagi et al. 2005; Hatta et al. 2002). Thus, it is likely that host-specific toxin biosynthetic genes may reside on $\mathrm{CD}$ chromosomes in the genomes of A. alternata pathotypes.

The distribution of supernumerary chromosomes in certain strains within the same fungal species and the patterns of repeated DNA sequences on certain supernumerary chromosomes suggest that they are of a different origin from the essential chromosomes in the same genome and that they may have been introduced into the genome by horizontal transfer from another species (Covert 1998; Enkerli et al. 1997; Hatta et al. 2006; Johnson et al. 2001; Rosewich and Kistler, 2000; Walton 2000). As the first step for elucidation of the structure, function, and origin of small chromosomes controlling hostspecific toxin biosynthesis in A. alternata, we here performed expressed sequence tag (EST) analysis of a 1.4-Mb chromosome encoding AMT genes in the apple pathotype strain IFO8984. We generated a cDNA library from AM-toxin-producing culture, selected 196 ESTs from 40,980 clones with the 1.4$\mathrm{Mb}$ chromosome probe, and identified 80 unigenes. Sequence analysis of these genes showed that the small chromosome predominantly encodes genes with unknown function. We also found that most of the genes encoded by this chromosome are expressed at markedly low levels under culture conditions tested. Comparison of the expression levels of the genes in AM-toxin-producing and nonproducing cultures identified candidates for novel AM-toxin biosynthetic genes.

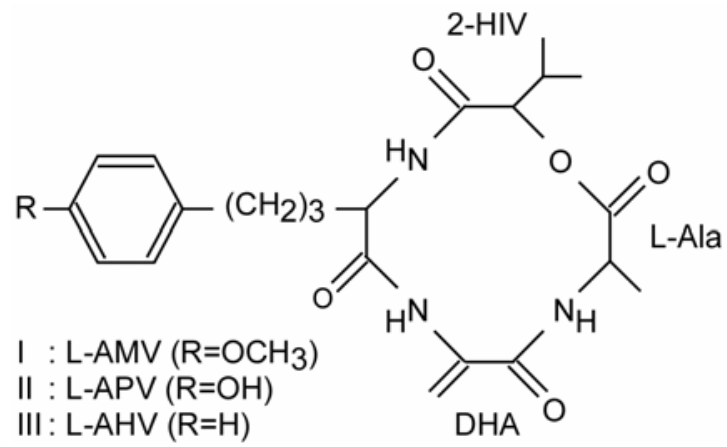

Fig. 1. AM-toxins produced by the apple pathotype of Alternaria alternata (Okuno et al. 1974; Ueno et al. 1977). L-AMV = L- $\alpha$-amino-methoxyphenyl-valeric acid; L-APV = L- $\alpha$-amino-phenyl-valeric acid; L-AHV = L$\alpha$-amino-hydroxyphenyl-valeric acid; 2-HIV =2-hydroxy-isovaleric acid; $\mathrm{L}-\mathrm{Ala}=\mathrm{L}-$ alanine$; \mathrm{DHA}=$ dehydroalanine.

\section{RESULTS AND DISCUSSION}

\section{Chromosomal distribution of $A M T$ genes in the apple pathotype strains.}

We examined the chromosomal distribution of the $A M T$ genes in six strains of the apple pathotype collected from different prefectures in Japan (Table 1). The chromosome-sized DNA of each strain was separated by PFGE under the conditions for separating DNA of the range 1.0 to $6.0 \mathrm{Mb}$. Although significant variability in electrophoretic karyotypes was observed among strains, all strains had small chromosomes of $<1.6 \mathrm{Mb}$. When the blots were hybridized with the AMT1 and AMT2 probes, both probes hybridized to small chromosomes of $<1.6 \mathrm{Mb}$ in all strains (Fig. 2A). Both genes were encoded by single, small chromosomes in five strains (IFO8984, FIVC45, M-71, FUJI-1, and O-6112) (Fig. 2A). Both genes, however, resided on not only a 1.6-Mb chromosome but also a 3.0$\mathrm{Mb}$ chromosome in strain HA-1 (Fig. 2A). These results suggest that AM-toxin biosynthetic genes are generally clustered on small chromosomes in the apple pathotype strains. We also found a strain of the strawberry pathotype, which has two chromosomes encoding the AF-toxin biosynthetic genes (AFT genes) (Hatta et al. 2002; 2006).

The blots were probed with the 1.4-Mb chromosome DNA of IFO8984 encoding AMT genes. This probe strongly hybridized to only the AMT-encoding chromosomes in IFO8984, FIVC-45, and M-71 (Fig. 2A), indicating that the AMT chromosomes of these strains are structurally unrelated to the other chromosomes in their genomes. In HA-1, FUJI-1, and O-6112, the chromosome probe hybridized to the $A M T$-encoding chromosomes with strong signals and an additional small chromosome with weaker signal (Fig. 2A). These small, AMT-noncoding chromosomes seem to be structurally similar to the $1.4-\mathrm{Mb}$ chromosome of IFO8984.

We previously observed that the CD chromosome DNA encoding toxin biosynthetic genes of the strawberry and tomato

Table 1. Strains of Alternaria alternata used in this study

\begin{tabular}{|c|c|c|}
\hline \multirow[b]{2}{*}{ Pathotype and strain ${ }^{a}$} & \multicolumn{2}{|c|}{ Origin } \\
\hline & Location & Source $^{b}$ \\
\hline \multicolumn{3}{|l|}{ Apple (AM-toxin) } \\
\hline IFO08984 & Unknown $^{\mathrm{c}}$ & IFO \\
\hline FIVC-45 & Aomori & AGBC \\
\hline HA-1 & Nagano & NFTES \\
\hline M-71 & Nagano & NFTES \\
\hline FUJI-1 & Akita & AFTES \\
\hline O-6112 & Iwate & IARC \\
\hline \multicolumn{3}{|l|}{ Strawberry (AF-toxin) } \\
\hline NAF8 & Aichi & NU \\
\hline \multicolumn{3}{|l|}{ Japanese pear (AK-toxin) } \\
\hline $15 \mathrm{~A}$ & Tottori & TU \\
\hline \multicolumn{3}{|l|}{ Tangerine (ACT-toxin) } \\
\hline ATCC38963 & United States & ATCC \\
\hline \multicolumn{3}{|l|}{ Rough lemon (ACR-toxin) } \\
\hline ATCC 38962 & United States & ATCC \\
\hline \multicolumn{3}{|l|}{ Tomato (AAL-toxin) } \\
\hline AL-4 & Mie & $\mathrm{NU}$ \\
\hline \multicolumn{3}{|l|}{ Tobacco (AT-toxin) } \\
\hline G-7a-I & Saga & SU \\
\hline \multicolumn{3}{|l|}{ Nonpathogen } \\
\hline IFO32416 & United States & IFO \\
\hline $\begin{array}{l}\text { a } \text { Host-specific toxin produ } \\
\text { b IFO, Institute for Fermen } \\
\text { Center, Aomori, Japan; I } \\
\text { Nagano, Japan; AFTES, } \\
\text { Japan; IARC, Iwate Ag } \\
\text { Nagoya University, Aich } \\
\text { ATCC, American Type C } \\
\text { University, Saga, Japan. } \\
\text { c Unknown, but in Japan. }\end{array}$ & $\begin{array}{l}\text { h pathotype is s } \\
\text { ka, Japan; AGB } \\
\text { gano Fruit Tree } \\
\text { ait Tree Experi } \\
\text { Research Cente } \\
\text { U, Tottori Univ } \\
\text { lection, Maryla }\end{array}$ & $\begin{array}{l}\text { n parentheses. } \\
\text { nori Green Bio } \\
\text { iment Station, } \\
\text { Station, Akita, } \\
\text { e, Japan; NU, } \\
\text { Tottori, Japan; } \\
\text {.A.; SU, Saga }\end{array}$ \\
\hline
\end{tabular}


pathotypes hybridized to no other chromosomes in the same genome of each pathotype (Akagi et al. 2005; Hatta et al. 2002). We found four kinds of class II transposon-like elements, which have incomplete transposase open reading frames (ORF) owing to either deletions, termination codons, or frameshifts, singly or in combination, in the $A F T$ cluster of the strawberry pathotype (Hatta et al. 2006). All the sequences appeared to be present specifically on the $A F T$ chromosomes in the genomes of the strawberry pathotype strains (Hatta et al. 2006). These observations suggest that small chromosomes encoding hostspecific toxin biosynthetic genes are of a different origin from the large, essential chromosomes in the genomes of these pathotypes.

Chromosome-sized DNA separated by PFGE was also probed with the fungal telomeric repeat sequences ([TTAGGG $]_{8}$ ) (Powell and Kistler 1990; Schechtman 1990). This probe hybridized to all bands including those of $<1.6 \mathrm{Mb}$ (Fig. 2B), confirming that the chromosome-sized DNA sequences encoding $A M T$ genes have the telomeres identical or very similar to those of fungal chromosomes.

\section{Construction of a cDNA library}

and single-pass sequencing of cDNAs.

As the first step for elucidation of the structure and function of the small chromosomes encoding AMT genes, we performed an EST analysis of the 1.4-Mb chromosome of IFO8984. On the basis of the genome size of A. alternata (about $30 \mathrm{Mb}$ ) (Akamatsu et al. 1999) and the general number of the fungal genes (about 10,000 genes), the 1.4-Mb chromosome is estimated to encode about 470 genes.

A cDNA library was constructed from poly $(\mathrm{A})^{+}$RNA isolated from IFO8984 mycelia grown in modified Czapek-Dox medium (MCD), in which the strain exhibited vigorous vegetative growth and produced AM-toxin. The library had about 2.7 $\times 10^{7} \mathrm{CFU}$ with the average insert size of $1.1 \mathrm{~kb}$. We could not definitely identify positive clones by direct colony hybridization of plated Escherichia coli with the 1.4-Mb chromosome probe, because the probe activity of each gene in the entire chromosome probe was relatively low. Thus, colonies were picked with sterilized toothpicks, and 200 clones were lined up on a Luria-Bertani (LB) plate $(9.5-\mathrm{cm}$ round plate), were grown, and were subjected to colony hybridization. A total of 40,980 colonies were screened with the $1.4-\mathrm{Mb}$ chromosome probe, and 265 positive clones were isolated. This selection frequency of positive clones was fairly low. We expected that about 1,900 positive clones could be isolated from 40,980 clones, because the 1.4-Mb chromosome accounts for $4.7 \%$ of the total genome. This result suggested that the genes encoded by the 1.4-Mb chromosome are expressed in MCD at lower levels than those encoded by the other chromosomes or that the gene density of the $1.4-\mathrm{Mb}$ chromosome is lower than those of the other chromosomes.

We subjected 265 positive clones to single-pass sequencing of the $3^{\prime}$ end of the cDNA (corresponding to the 5', nonpoly[A] tail end of the mRNA) and obtained quality sequences with an average length of 546 bases. The average guanine plus cytosine content of obtained sequences is $52.7 \%$. The 265 EST sequences were assembled into 37 overlapping contigs (2 to 17 ESTs) and 100 singletons, and thus, 137 unigenes were identified. To confirm that these genes are encoded by the $1.4-\mathrm{Mb}$ chromosome, each gene fragment was amplified from total DNA and the 1.4-Mb chromosome DNA by polymerase chain reaction (PCR). Because the 1.4-Mb chromosome DNA recovered from PFGE gel contained low levels of other chromosomal DNA, we used a DNA mixture of 78 bacterial artificial chromosome (BAC) clones that contained the 1.4-Mb chromosome DNA as a PCR template. The average insert size of these BAC clones was $85.7 \mathrm{~kb}$, and their total insert size $(6,684.6$ $\mathrm{kb}$ ) was about fivefold of the $1.4-\mathrm{Mb}$ chromosome. PCR with primers designed for 80 genes amplified DNA from both total DNA and BAC DNA mixtures. However, PCR with primers for the remaining 57 genes produced DNA from total DNA but not from the BAC DNA mixture. Thus, at least 80 of 137 genes identified are encoded by the 1.4-Mb chromosome, and 196 of 265 ESTs selected were derived from these genes. The remaining genes may consist of paralogs of the $1.4-\mathrm{Mb}$ chromosome genes residing on any other chromosomes and falsepositive clones.

\section{Functional annotation.}

The unigene sequences were compared with the nonredundant database from the National Center for Biotechnology Information (NCBI) using the BLASTX algorithms (Altschul et al. 1997) and were given a putative functional assignment according to the classification developed by the Saccharomyces cerevisiae functional catalog by the Munich Information Center for Protein Sequences (MIPS) (Mewes et al. 1997, 2002). On the basis of BLASTX homology searches, 80 genes were classified into 13 MIPS functional groups (Table 2). Categories "AMtoxin biosynthesis" and "conserved hypothetical protein" were added as new categories for the 1.4-Mb chromosome genes.

BLASTX analysis revealed matches against the nonredundant databases from NCBI for 46 of 80 genes, using a cutoff expected $(E)$ value of $1 \mathrm{E}-5$ (Table 2). The remaining 34 genes $(43 \%)$ were designated as "no hit." Additional database searches of these genes, using 23 fungal genome databases at the Broad
A

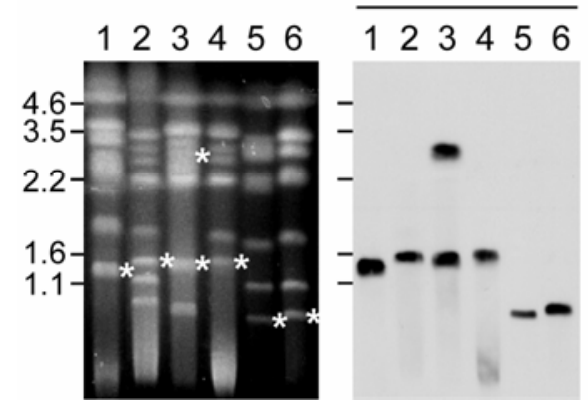

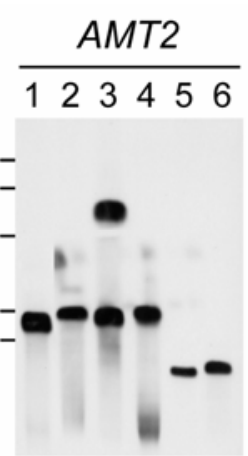

$\frac{1.4-\mathrm{Mb} \mathrm{chr}}{123456}$

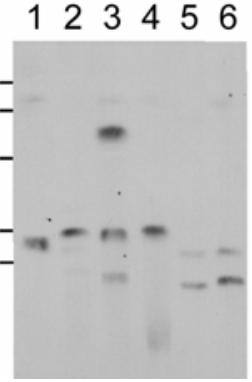

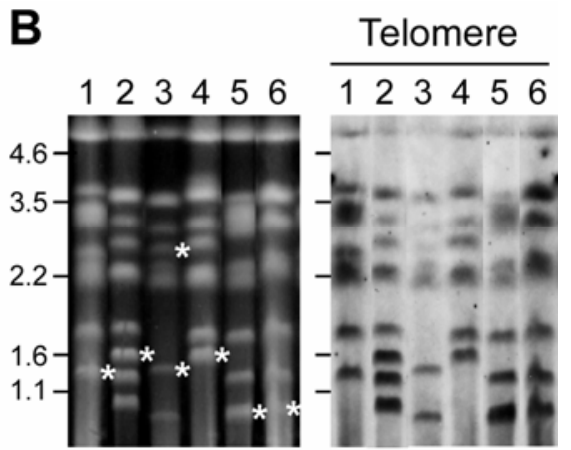

Fig. 2. Chromosomal distribution of $A M T 1$ and $A M T 2$ in the apple pathotype strains. Chromosome-sized DNA of each strain was separated by contourclamped homogeneous electric field electrophoresis under conditions for 1.0- to 6.0-Mb DNA. The blots were hybridized with A, probes from AMT1, AMT2, and the 1.4-Mb chromosome of the apple pathotype strain IFO8984 and B, fungal telomeric repeat sequence [(TTAGGG) 8 . The asterisks indicate chromosomal DNA intensely hybridized with both AMT1 and AMT2 probes. Sizes (in megabases) of chromosomes of Saccharomyces cerevisiae and Schizosaccharomyces pombe are indicated on the left. Lanes 1 to 6, strains IFO8984, FIVC-45, HA-1, M-71, FUJI-1, and O-6112. 
Institute and the United States Department of Energy (DOE) Joint Genome Institute websites, revealed that five of 34 no hit genes have similarity to hypothetical proteins with unknown function. The remaining 29 no hit genes (36\% of unigenes) have no significant homology to anything currently residing in the fungal genome databases and could be considered as A. alternata-specific (Table 2). In the Magnaporthe grisea and Ustilago maydis genomes, the orphan sequences make up 20 and $11 \%$, respectively, of predicted protein-coding sequences (Dean et al. 2005; Kämper et al. 2006). Presence of many orphan sequences on the 1.4-Mb chromosome may be one of the structural characteristics of supernumerary chromosomes. Together with the con- served hypothetical protein category (14 genes), 43 genes (54\% of identified unigenes) are of unknown function. Of 51 genes having similarity to any sequences deposited in databases $(E$ value $<1 \mathrm{E}-5), 46$ have the highest similarity to genes from the filamentous ascomycetes (Table 2).

Fungal genome databases at the DOE Joint Genome Institute website include that of $N$. haematococca MPIV, which is known to have the $1.6-\mathrm{Mb}$ supernumerary chromosome controlling pathogenicity on pea. We are interested in comparing the types of genes encoded by supernumerary chromosomes of $A$. alternata and $N$. haematoccoca. The 80 unigene sequences encoded by the 1.4-Mb chromosome of A. alternata were compared with

Table 2. Functional classification and expression profiles of genes encoded by the 1.4-Mb chromosome of the apple pathotype of Alternaria alternata

\begin{tabular}{|c|c|c|c|c|c|c|}
\hline \multirow[b]{2}{*}{ Category and clone $^{a}$} & \multirow[b]{2}{*}{ Accession no. } & \multirow[b]{2}{*}{ Best BLASTX match } & \multirow[b]{2}{*}{$E$ value } & \multicolumn{2}{|c|}{ Relative to $E F 1-\alpha^{b}$} & \multirow[b]{2}{*}{$\mathrm{MCD} / \mathrm{PDB}^{\mathrm{c}}$} \\
\hline & & & & MCD & PDB & \\
\hline \multicolumn{7}{|c|}{ 01. AM-toxin biosynthesis } \\
\hline$A M T 2$ & AB119281 & Aldo-keto reductase (Alternaria alternata) & & $3.7 \mathrm{E}-2$ & $2.9 \mathrm{E}-5$ & $1,248.80$ \\
\hline$A M T 1$ & AF184074 & AM-toxin synthase (Alternaria alternata) & & $2.1 \mathrm{E}-2$ & $3.6 \mathrm{E}-4$ & 57.11 \\
\hline \multicolumn{7}{|l|}{ 02. Metabolism } \\
\hline IFO_3_84 & CI999863 & Polyketide synthase (Botryotinia fuckeliana) & $6.0 \mathrm{E}-10$ & $1.1 \mathrm{E}-2$ & $6.9 \mathrm{E}-7$ & $16,561.43$ \\
\hline IFO_1_33 & CI999790 & 2-Isopropylmalate synthase (Aspergillus fumigatus) & $8.0 \mathrm{E}-41$ & 4.9E-3 & $6.9 \mathrm{E}-6$ & 714.13 \\
\hline IFO_3_25 & CI999853 & $\begin{array}{l}\text { 3-Isopropylmalate dehydrogenase (Mycosphaerella } \\
\text { graminicola) }\end{array}$ & $1.0 \mathrm{E}-36$ & $3.9 \mathrm{E}-4$ & $3.8 \mathrm{E}-6$ & 101.70 \\
\hline IFO_2_10 & CI999821 & $\begin{array}{l}\text { Branched-chain amino acid aminotransferase (Aspergillus } \\
\text { fumigatus) }\end{array}$ & $5.0 \mathrm{E}-46$ & $9.5 \mathrm{E}-3$ & $1.6 \mathrm{E}-4$ & 60.70 \\
\hline IFO_1_88 & CI999813 & Nonribosomal peptide synthetase (Trichoderma atroviride) & $8.0 \mathrm{E}-34$ & $2.9 \mathrm{E}-3$ & $8.6 \mathrm{E}-5$ & 34.19 \\
\hline IFO_1_35 & CI999792 & $\begin{array}{l}\text { Fum12p (cytochrome P450 monoxygenase) (Gibberella } \\
\text { moniliformis) }\end{array}$ & $8.0 \mathrm{E}-71$ & $1.8 \mathrm{E}-2$ & $5.9 \mathrm{E}-4$ & 29.95 \\
\hline IFO_1_11 & CI999784 & $O$-methyltransferase (Aspergillus parasiticus) & $1.0 \mathrm{E}-10$ & $2.2 \mathrm{E}-2$ & $1.0 \mathrm{E}-3$ & 22.21 \\
\hline IFO_1_18 & CI999787 & $\begin{array}{l}\text { Nonribosomal peptide synthetase } 1 \text { (Cochliobolus } \\
\text { heterostrophus) }\end{array}$ & $1.0 \mathrm{E}-31$ & 7.4E-4 & $4.5 \mathrm{E}-5$ & 16.45 \\
\hline IFO_1_41 & CI999797 & $\begin{array}{l}\text { 3-deoxy-D-arabino-heptulosonate-7-phosphate synthase } \\
\text { (Aspergillus nidulans) }\end{array}$ & $3.0 \mathrm{E}-157$ & $5.1 \mathrm{E}-4$ & $1.7 \mathrm{E}-4$ & 3.06 \\
\hline IFO_1_21 & CI999788 & Acetyl-CoA acetyltransferase (Aspergillus fumigatus) & $6.0 \mathrm{E}-67$ & $2.4 \mathrm{E}-2$ & $8.2 \mathrm{E}-3$ & 2.95 \\
\hline IFO_2_54 & CI999836 & Carotenoid oxygenase (Gibberella fujikuroi) & $5.0 \mathrm{E}-52$ & $3.9 \mathrm{E}-2$ & $1.6 \mathrm{E}-2$ & 2.47 \\
\hline IFO_4_33 & CI999876 & Maltose o-acetyltransferase (Nitrosospira multiformis) & $1.0 \mathrm{E}-18$ & $3.7 \mathrm{E}-3$ & $8.0 \mathrm{E}-3$ & 0.46 \\
\hline IFO_1_51 & CI999804 & Aristolochene synthase (Aspergillus terreus) & $4.0 \mathrm{E}-40$ & 9.9E-5 & $6.1 \mathrm{E}-4$ & 0.16 \\
\hline IFO_1_15 & CI999786 & 1,3,8-naphthalenetriol reductase (Embellisia allii) & $6.0 \mathrm{E}-69$ & $6.9 \mathrm{E}-4$ & $1.4 \mathrm{E}-2$ & 0.05 \\
\hline \multicolumn{7}{|l|}{ 03. Energy } \\
\hline IFO_5_86 & CI999916 & Aconitate hydratase (Aspergillus fumigatus) & $1.0 \mathrm{E}-90$ & $5.0 \mathrm{E}-3$ & $2.5 \mathrm{E}-6$ & $2,035.25$ \\
\hline IFO_4_08 & CI999868 & ATP citrate lyase subunit 1 (Neurospora crassa) & 7.0E-20 & $3.1 \mathrm{E}-3$ & $1.1 \mathrm{E}-3$ & 2.84 \\
\hline \multicolumn{7}{|l|}{ 04. Transcription } \\
\hline IFO_5_87 & CI999917 & Transcription activator amyR (Neurospora crassa) & $3.0 \mathrm{E}-34$ & $1.1 \mathrm{E}-3$ & $7.5 \mathrm{E}-4$ & 1.42 \\
\hline IFO_4_52 & CI999882 & Transcriptional regulator (Aspergillus fumigatus) & $3.0 \mathrm{E}-51$ & $6.7 \mathrm{E}-3$ & $6.3 \mathrm{E}-3$ & 1.08 \\
\hline IFO_2_75 & CI999839 & Mpe1p (Saccharomyces cerevisiae) & $3.0 \mathrm{E}-17$ & $2.9 \mathrm{E}-3$ & $4.6 \mathrm{E}-3$ & 0.64 \\
\hline \multicolumn{7}{|l|}{ 05. Protein synthesis } \\
\hline IFO_4_42 & CI999879 & 60S ribosomal protein L27a (Gibberella zeae) & $3.0 \mathrm{E}-65$ & $4.0 \mathrm{E}-1$ & $8.1 \mathrm{E}-1$ & 0.50 \\
\hline \multicolumn{7}{|l|}{ 06. Protein fate } \\
\hline IFO_4_07 & CI999867 & Zinc metalloprotease (Aspergillus fumigatus) & $1.0 \mathrm{E}-42$ & $1.1 \mathrm{E}-2$ & $9.7 \mathrm{E}-3$ & 1.14 \\
\hline IFO_1_31 & CI999789 & Ubiquitin-protein ligase Tom1 (Aspergillus fumigatus) & $6.0 \mathrm{E}-55$ & $4.1 \mathrm{E}-4$ & $1.0 \mathrm{E}-3$ & 0.40 \\
\hline \multicolumn{7}{|c|}{ 07. Cellular transport, transport facilitation and transport routes } \\
\hline IFO_4_31 & CI999875 & Mitochondrial carrier protein (Aspergillus fumigatus) & $2.0 \mathrm{E}-86$ & $1.6 \mathrm{E}-2$ & 7.7E-3 & 2.01 \\
\hline IFO_1_50 & CI999803 & Calcium-translocating P-type ATPase (Aspergillus fumigatus) & $2.0 \mathrm{E}-53$ & $1.9 \mathrm{E}-4$ & $1.4 \mathrm{E}-3$ & 0.14 \\
\hline \multicolumn{7}{|c|}{ 08. Cell rescue, defense and virulence } \\
\hline IFO_2_05 & CI999818 & Thioredoxin (Paracoccidioides brasiliensis) & $2.0 \mathrm{E}-22$ & $2.4 \mathrm{E}-1$ & $2.0 \mathrm{E}-2$ & 11.90 \\
\hline IFO_2_50 & CI999834 & BcpB (Azotobacter vinelandii) & $4.0 \mathrm{E}-52$ & $2.5 \mathrm{E}-3$ & $4.0 \mathrm{E}-3$ & 0.63 \\
\hline \multicolumn{7}{|c|}{ 09. Transposable elements, viral and plasmid proteins } \\
\hline IFO_1_39 & CI999795 & Polyprotein (Stagonospora nodorum) & $5.0 \mathrm{E}-45$ & $1.5 \mathrm{E}-1$ & $2.5 \mathrm{E}-3$ & 60.63 \\
\hline IFO_1_40 & CI999796 & Polyprotein (Stagonospora nodorum) & $4.0 \mathrm{E}-47$ & 8.3E-3 & $1.8 \mathrm{E}-4$ & 47.21 \\
\hline IFO_1_34 & CI999791 & Polyprotein (Stagonospora nodorum) & $2.0 \mathrm{E}-37$ & 4.1E-2 & $9.4 \mathrm{E}-4$ & 43.22 \\
\hline \multirow[t]{2}{*}{ IFO_2_34 } & CI999828 & Transposase (Aspergillus fumigatus) & $1.0 \mathrm{E}-23$ & $2.3 \mathrm{E}-2$ & $1.3 \mathrm{E}-2$ & 1.80 \\
\hline & & & & \multicolumn{3}{|c|}{ Continued on following page } \\
\hline
\end{tabular}

${ }^{a}$ Unigenes were compared to the nonredundant databases from NCBI, the Broad Institute, and the DOE Joint Genome Institute with the BLASTX tool and were placed in each MIPS category according to the function of a matching gene. $E$-values greater than $1.0 \mathrm{e}-5$ were considered to be insignificant and are listed as "no hit".

${ }^{\mathrm{b}}$ Compared to EF1- $\alpha$ mRNA. Each value represents the mean of two experiments with independently isolated RNA and subsequently synthesized cDNA samples. MCD, AM-toxin producing culture; PDB, AM-toxin nonproducing culture.

${ }^{c}$ Mean expression in MCD/mean expression in PDB. 
those of five contigs (Scaffold_23, 24, 62, 63, and 131) corresponding to the $1.6-\mathrm{Mb}$ chromosome of $N$. haematoccoca. These contigs appeared to have only four genes with significant similarity to the A. alternata genes (IFO_1_15, IFO_1_35, IFO_1_49, and IFO_3_53). These results suggest that supernumerary chromosomes of these two fungi are different in structure and origin.

The "metabolism" category included eight genes possibly involved in secondary metabolism (Table 2). Of the eight genes, five have similarity to enzymes involved in known secondary metabolisms: fumonisin of Gibberella moniliformis (IFO_1_35) (Proctor et al. 2003), aristolochene of Aspergillus terreus (IFO_1_51) (Cane and Kang 2000), aflatoxin of $A$. parasiticus (IFO_1_11) (Yu et al. 2004), carotenoid of G. fujikuroi (IFO_2_54) (Thewes et al. 2005), and melanin of Embellisia allii (IFO_1_15) (GenBank accession number BAD13328). IFO_3_84 shows similarity to putative polyketide synthase (Kroken et al. 2003), and IFO_1_18 and IFO_1_88 are homologous to putative nonribosomal peptide synthetases (Lee et al. 2005; Vizcaino et al. 2005).

IFO_1_15 has the highest similarity to 1,3,8-trihydroxynaphthalene $(1,3,8-\mathrm{THN})$ reductases involved in fungal melanin biosynthesis. We previously isolated the 1,3,8-THN reductase gene $(B R M 2)$ from strain 15A of the Japanese pear pathotype and identified its essential function in melanin biosynthesis (Kawamura et al. 1999). Targeted disruption of BRM2 in 15A

Table 2. Continued from preceding page

\begin{tabular}{|c|c|c|c|c|c|c|}
\hline \multirow[b]{2}{*}{ Category and clone $\mathrm{a}^{\mathrm{a}}$} & \multirow[b]{2}{*}{ Accession no. } & \multirow[b]{2}{*}{ Best BLASTX match } & \multirow[b]{2}{*}{$E$ value } & \multicolumn{2}{|c|}{ Relative to $E F 1-\alpha^{b}$} & \multirow[b]{2}{*}{$\mathrm{MCD} / \mathrm{PDB}$} \\
\hline & & & & MCD & PDB & \\
\hline \multicolumn{7}{|c|}{ 09. Transposable elements, viral and plasmid proteins (Continued) } \\
\hline IFO_1_72 & CI999809 & Reverse transcriptase, RNaseH (Aspergillus fumigatus) & $2.0 \mathrm{E}-20$ & $1.5 \mathrm{E}-3$ & $1.5 \mathrm{E}-3$ & 0.99 \\
\hline IFO_2_01 & CI999815 & Putative transposase (Stagonospora nodorum) & $3.0 \mathrm{E}-6$ & ND & ND & \\
\hline \multicolumn{7}{|c|}{ 10. Biogenesis of cellular components } \\
\hline IFO_5_57 & CI999912 & ECM4 protein (Neurospora crassa) & $4.0 \mathrm{E}-18$ & $5.4 \mathrm{E}-5$ & $5.6 \mathrm{E}-4$ & 0.10 \\
\hline \multicolumn{7}{|c|}{ 11. Classification not yet clear-cut } \\
\hline IFO_4_19 & CI999873 & Fe-S protein (Burkholderia pseudomallei) & $6.0 \mathrm{E}-8$ & $8.2 \mathrm{E}-2$ & 7.9E-2 & 1.04 \\
\hline IFO_1_61 & CI999807 & Proteophosphoglycan 5 (Leishmania major) & $1.0 \mathrm{E}-6$ & $1.5 \mathrm{E}-4$ & $1.6 \mathrm{E}-3$ & 0.10 \\
\hline \multicolumn{7}{|c|}{ 12. Conserved hypothetical protein } \\
\hline IFO_4_61 & CI999885 & Predicted protein SNOG_02571 (Stagonospora nodorum) & $7.0 \mathrm{E}-47$ & $2.0 \mathrm{E}-2$ & $1.7 \mathrm{E}-4$ & 116.56 \\
\hline IFO_5_07 & CI999896 & Hypothetical protein UM06256.1 (Ustilago maydis) & $9.0 \mathrm{E}-6$ & $1.1 \mathrm{E}-3$ & $1.4 \mathrm{E}-5$ & 79.16 \\
\hline IFO_1_57 & CI999806 & Predicted protein SNOG_02571 (Stagonospora nodorum) & $2.0 \mathrm{E}-46$ & $1.1 \mathrm{E}-2$ & $1.8 \mathrm{E}-4$ & 62.46 \\
\hline IFO_2_48 & CI999833 & Predicted protein SNOG_10333 (Stagonospora nodorum) & $1.0 \mathrm{E}-11$ & $4.0 \mathrm{E}-1$ & $3.0 \mathrm{E}-2$ & 13.29 \\
\hline IFO_3_29 & CI999854 & Unknown (Schistosoma japonicum) & $6.0 \mathrm{E}-9$ & $1.8 \mathrm{E}-8$ & $1.4 \mathrm{E}-8$ & 1.34 \\
\hline IFO_4_40 & CI999878 & Hypothetical protein AN4077.2 (Aspergillus nidulans) & $6.0 \mathrm{E}-23$ & $3.4 \mathrm{E}-3$ & $2.7 \mathrm{E}-3$ & 1.26 \\
\hline IFO_3_53 & CI999859 & $\begin{array}{l}\text { estExt_fgenesh1_pg.C_sca_23_chr14_3_00002 (Nectria } \\
\text { haematococca) }\end{array}$ & $2.0 \mathrm{E}-85$ & $2.5 \mathrm{E}-3$ & $2.8 \mathrm{E}-3$ & 0.89 \\
\hline IFO_4_17 & CI999872 & e_gw.8.1133.1 (Mycosphaerella graminicola) & $3.0 \mathrm{E}-24$ & $2.7 \mathrm{E}-3$ & $3.1 \mathrm{E}-3$ & 0.88 \\
\hline IFO_1_49 & CI999802 & Predicted protein (Magnaporthe grisea) & $1.0 \mathrm{E}-15$ & $1.6 \mathrm{E}-2$ & $2.2 \mathrm{E}-2$ & 0.74 \\
\hline IFO_1_89 & CI999814 & Hypothetical protein AN5233.2 (Aspergillus nidulans) & $5.0 \mathrm{E}-26$ & $2.6 \mathrm{E}-4$ & $4.0 \mathrm{E}-4$ & 0.66 \\
\hline IFO_4_14 & CI999870 & Hypothetical protein SNOG_13110 (Stagonospora nodorum) & $3.0 \mathrm{E}-37$ & $5.1 \mathrm{E}-3$ & $9.4 \mathrm{E}-3$ & 0.54 \\
\hline IFO_4_60 & CI999884 & Hypothetical protein SNOG_05490 (Stagonospora nodorum) & $6.0 \mathrm{E}-36$ & $1.4 \mathrm{E}-3$ & $1.1 \mathrm{E}-2$ & 0.12 \\
\hline IFO_5_70 & CI999913 & Hypothetical protein FG05606.1 (Gibberella zeae) & $3.0 \mathrm{E}-21$ & $5.9 \mathrm{E}-4$ & $6.1 \mathrm{E}-3$ & 0.10 \\
\hline IFO_5_28 & CI999902 & gw.115.5.1 (Mycosphaerella graminicola) & $2.0 \mathrm{E}-17$ & ND & ND & \\
\hline \multicolumn{7}{|l|}{ 13. No hit } \\
\hline IFO_2_43 & CI999831 & & & $1.4 \mathrm{E}-4$ & $1.3 \mathrm{E}-7$ & $1,061.12$ \\
\hline IFO_1_85 & CI999812 & & & $1.2 \mathrm{E}-2$ & $8.3 \mathrm{E}-4$ & $1,3.91$ \\
\hline IFO_3_13 & CI999849 & & & $2.1 \mathrm{E}-2$ & $3.7 \mathrm{E}-3$ & 5.67 \\
\hline IFO_1_45 & CI999800 & & & $5.2 \mathrm{E}-4$ & $3.5 \mathrm{E}-4$ & 1.51 \\
\hline IFO_5_34 & CI999905 & & & $1.9 \mathrm{E}-2$ & $1.4 \mathrm{E}-2$ & 1.41 \\
\hline IFO_1_37 & CI999794 & & & $2.3 \mathrm{E}-3$ & $2.4 \mathrm{E}-3$ & 0.97 \\
\hline IFO_2_02 & CI999816 & & & $1.6 \mathrm{E}-2$ & $1.7 \mathrm{E}-2$ & 0.96 \\
\hline IFO_2_91 & CI999843 & & & $3.9 \mathrm{E}-3$ & $6.0 \mathrm{E}-3$ & 0.65 \\
\hline IFO_2_25 & CI999825 & & & $3.2 \mathrm{E}-3$ & $5.9 \mathrm{E}-3$ & 0.54 \\
\hline IFO_6_10 & CI999919 & & & $5.8 \mathrm{E}-3$ & $1.1 \mathrm{E}-2$ & 0.53 \\
\hline IFO_1_42 & CI999798 & & & $3.7 \mathrm{E}-2$ & 7.6E-2 & 0.49 \\
\hline IFO_2_31 & CI999827 & & & $3.6 \mathrm{E}-3$ & 7.6E-3 & 0.47 \\
\hline IFO_2_44 & CI999832 & & & $3.9 \mathrm{E}-3$ & $8.9 \mathrm{E}-3$ & 0.44 \\
\hline IFO_1_56 & CI999805 & & & $1.9 \mathrm{E}-3$ & $4.3 \mathrm{E}-3$ & 0.43 \\
\hline IFO_4_37 & CI999877 & & & $2.6 \mathrm{E}-4$ & $7.3 \mathrm{E}-4$ & 0.35 \\
\hline IFO_1_05 & CI999780 & & & 4.9E-2 & $1.9 \mathrm{E}-1$ & 0.25 \\
\hline IFO_3_21 & CI999851 & & & $5.7 \mathrm{E}-5$ & $3.5 \mathrm{E}-4$ & 0.17 \\
\hline IFO_1_83 & CI999811 & & & 4.7E-4 & $3.0 \mathrm{E}-3$ & 0.16 \\
\hline IFO_2_40 & CI999829 & & & 7.1E-5 & $5.4 \mathrm{E}-4$ & 0.13 \\
\hline IFO_3_11 & CI999848 & & & $2.5 \mathrm{E}-3$ & $2.0 \mathrm{E}-2$ & 0.13 \\
\hline IFO_5_79 & CI999914 & & & $3.8 \mathrm{E}-6$ & $3.4 \mathrm{E}-5$ & 0.11 \\
\hline IFO_3_02 & CI999846 & & & $1.3 \mathrm{E}-3$ & $1.3 \mathrm{E}-2$ & 0.10 \\
\hline IFO_4_06 & CI999866 & & & $5.7 \mathrm{E}-4$ & $5.9 \mathrm{E}-3$ & 0.10 \\
\hline IFO_1_06 & CI999781 & & & $2.1 \mathrm{E}-4$ & $2.9 \mathrm{E}-3$ & 0.07 \\
\hline IFO_3_41 & CI999856 & & & $1.3 \mathrm{E}-8$ & $1.8 \mathrm{E}-7$ & 0.07 \\
\hline IFO_3_10 & CI999847 & & & ND & ND & \\
\hline IFO_4_95 & CI999894 & & & ND & ND & \\
\hline IFO_5_46 & CI999909 & & & ND & ND & \\
\hline IFO_5_48 & CI999910 & & & & ND & ND \\
\hline
\end{tabular}


made melanin-deficient, brown mutants. We also identified that three melanin biosynthetic genes ( $A L M, B R M 1$, and $B R M 2$ ) are clustered on the largest chromosomes in A. alternata strains (Akamatsu et al. 1999; Kimura and Tsuge 1993). The IFO_1_15-encoded protein has 66\% amino-acid sequence identity to the corresponding region of Brm2. We analyzed distribution of IFO_1_15 in strains from seven pathotypes and nonpathogenic A. alternata (Table 1) by DNA gel blot analysis. The IFO_1_15 probe hybridized to DNA from strains of five pathotypes (apple, strawberry, Japanese pear, tangerine, and rough lemon) but not to DNA from the other strains (Fig. 3), indicating that this gene is not conserved in A. alternata. Because $15 \mathrm{~A}$ of the Japanese pear pathotype has the homolog, this gene is a homolog but not a paralog of $B R M 2$, essential for melanin biosynthesis in A. alternata.

We previously proposed that small chromosomes encoding $A M T$ genes of the apple pathotype are $\mathrm{CD}$ chromosomes (Johnson et al. 2001). However, the 1.4-Mb chromosome of IFO8984 appeared to encode genes with strong similarity to basic metabolism and cellular component proteins. IFO_4_08 and IFO_5_86 are predicted to encode ATP citrate lyase subunit 1 and aconitate hydratase involved in the tricarboxylic acid cycle (Gangloff et al. 1990). IFO_4_42 encodes the 60S ribosomal protein L27a (Fatica and Tollervey 2002). IFO_1_33, IFO_3_25, and IFO_2_10 have similarity to enzymes for biosynthesis of leucine from valine (Kohlhaw 2003). IFO_1_41 is predicted to encode 3-deoxy-D-arabinoheptulosonate-7-phosphate (DAHP) synthase that catalyzes the first step of the aromatic amino-acid biosynthetic pathway (Hartmann et al. 2001). We speculated that IFO8984 has additional copies of these genes on any other chromosomes and thus analyzed the chromosomal distribution of these genes.
Chromosomal distribution of putative housekeeping genes.

The chromosome-sized DNA of IFO8984 was separated by PFGE under the conditions for separating DNA of $<2.0 \mathrm{Mb}$, and the blots were probed with the seven-clone DNA. IFO_4_08 (ATP citrate lyase subunit 1) probe hybridized to two chromosomes of 1.4 and $1.9 \mathrm{Mb}$ with similar signal intensity, indicating that IFO8984 has an additional copy of this gene on the 1.9-Mb chromosome (Fig. 4). IFO_3_25 (3-isopropylmalate dehydrogenase) and IFO_4_42 (60S ribosomal protein L27a) probes hybridized strongly to $1.4-\mathrm{Mb}$ chromosome and weakly to $>2.0$ $\mathrm{Mb}$ chromosome (Fig. 4), suggesting that these genes are paralogs or homologs of housekeeping genes encoded by other chromosomes in the genome. However, the remaining four clones (IFO_1_33, IFO_1_41, IFO_2_10, and IFO_5_86) hybridized to only a 1.4-Mb chromosome (Fig. 4) and are probably derived from 1.4-Mb chromosome-specific genes.

To assess whether these clones correspond to the conserved housekeeping genes in A. alternata, we analyzed distribution of these genes in strains from seven pathotypes and nonpathogenic A. alternata (Table 1). IFO_3_25 was also analyzed for the distribution in A. alternata strains because IFO_1_33, IFO_2_10, and IFO_3_25 possibly encode a set of enzymes catalyzing different steps in leucine biosynthesis. IFO_1_33 and IFO_2_10 probes hybridized to DNA from only the apple pathotype strains, indicating that these genes do not encode leucine biosynthetic enzymes conserved in A. alternata (Fig. $3)$. IFO_3_25 probe hybridized to two (4.0 and $4.8 \mathrm{~kb}$ ) or three bands $(2.4,4.0$, and $4.8 \mathrm{~kb})$ in the apple pathotype strains (Fig. 3 ). This probe also hybridized to single bands in all strains from the other pathotypes and nonpathogenic A. alternata, a $6.8-\mathrm{kb}$ band in the strawberry pathotype strain NAF8 and 4.0$\mathrm{kb}$ bands in the other strains (Fig. 3). This result suggests that

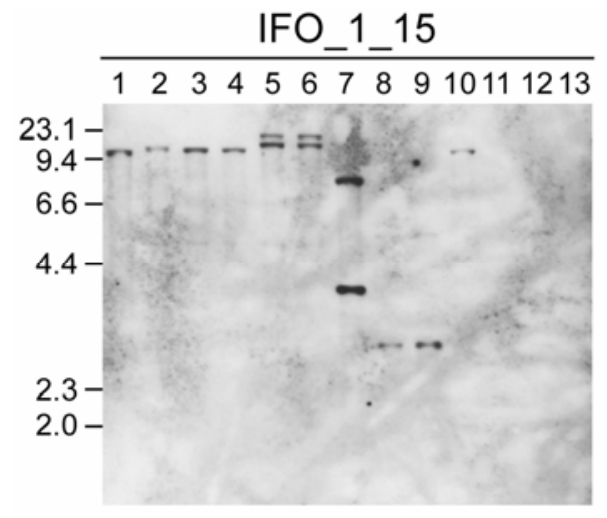

IFO_2_10

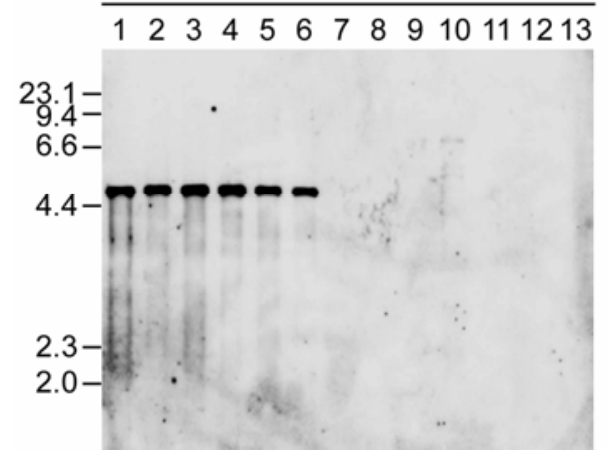

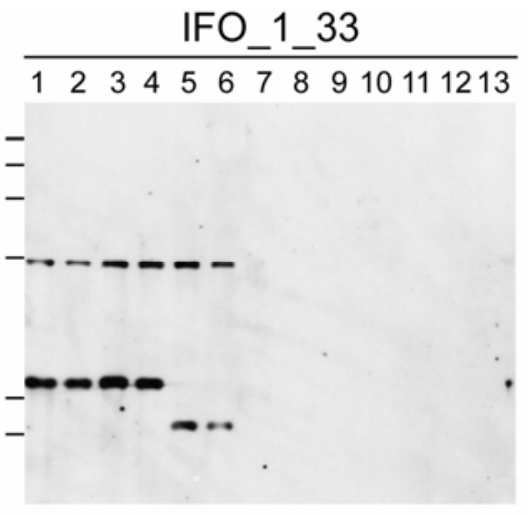

IFO_3_25

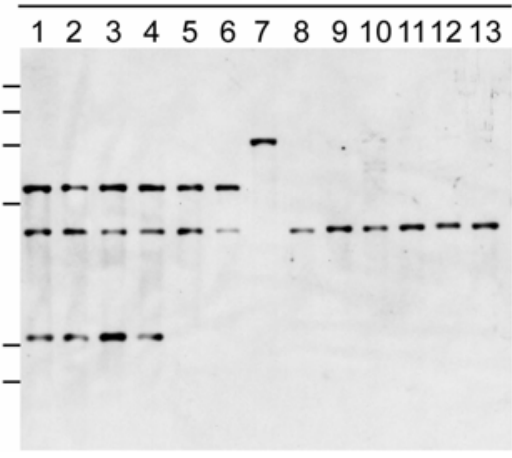

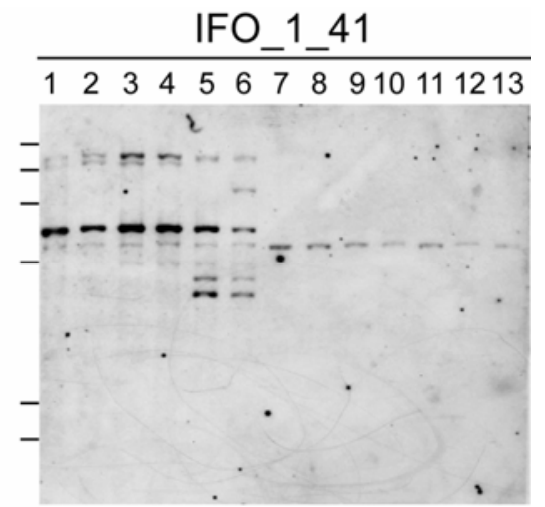

IFO_5_86
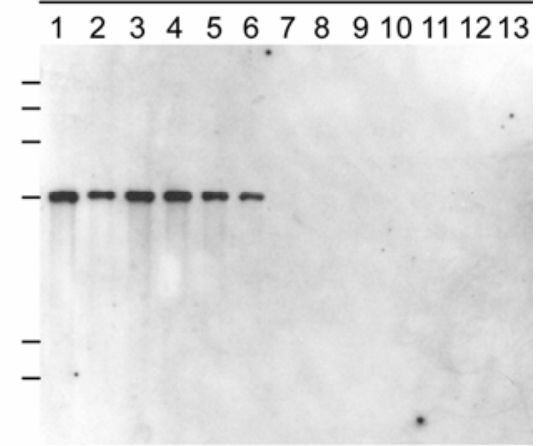

Fig. 3. Distribution of cDNA clones encoded by the 1.4-Mb chromosome of the apple pathotype strain IFO8984 in Alternaria alternata strains. Total DNA of each strain was digested with EcoRV and was separated in $0.8 \%$ agarose gels. The blots were hybridized with the cDNA probes. Sizes (in kilobases) of marker DNA fragments (HindIII-digested 2DNA) are indicated on the left. Lanes 1 to 6, IFO8984, FIVC-45, HA-1, M-71, FUJI-1, and O-6112 (apple pathotype); lanes 7 to 13, NAF8 (strawberry pathotype), 15A (Japanese pear pathotype), ATCC38963 (tangerine pathotype), ATCC38962 (rough lemon pathotype), AL-4 (tomato pathotype), G-7a-I (tobacco pathotype), and IFO32416 (nonpathogenic A. alternata). 
the 4.0-kb bands in the apple pathotype strains correspond to 3-isopropylmalate dehydrogenase genes for leucine biosynthesis and that additional bands specifically detected in the apple pathotype strains correspond to its homologs.

IFO_1_41 (DAHP synthase) probe hybridized strongly to $5.3 \mathrm{~kb}$ bands and weakly to additional multiple bands in the apple pathotype strains (Fig. 3). This probe visualized $5.0-\mathrm{kb}$ bands with weak signals in all strains from the other pathotypes and nonpathogenic A. alternata, and 5.0-kb bands were also detected in the apple pathotype strains (Fig. 3). This result suggests that the $5.0-\mathrm{kb}$ bands encode DAHP synthase conserved in A. alternata. We found an EST clone IFO_3_96, which was included in the 135 unigenes initially selected. However, this clone was found not to reside on the 1.4-Mb chromosome by PCR analysis as described. This clone also has significant similarity to DAHP synthase of $A$. nidulans (Hartmann et al. 2001) and has $84 \%$ nucleotide sequence identity to the corresponding region of IFO_1_41. Thus, IFO_3_96 probably encodes DAHP synthase conserved in A. alternata.

IFO_5_86 probe hybridized to DNA from only the apple pathotype strains (Fig. 3), indicating that IFO_5_86 does not encode aconitate hydratase conserved in A. alternata. These analyses of seven putative housekeeping genes on the 1.4-Mb chromosome suggest that they are extra copies or homologs of housekeeping genes.

AM-toxin has been characterized as three related molecular species, AM-toxins I, II, and III, which contain aromatic amino-acid derivatives L- $\alpha$-amino-methoxyphenyl-valeric acid, L- $\alpha$-amino-phenyl-valeric acid, and L- $\alpha$-amino-hydroxyphenyl-valeric acid, respectively (Fig. 1). IFO_1_41 is predicted to encode DAHP synthase that catalyzes the first step of the aromatic amino-acid biosynthetic pathway. The aromatic amino-acid derivatives in AM-toxins have longer carbon chains than natural aromatic amino acids. IFO_1_33, IFO_2_10, and IFO_3_25 have similarity to enzymes that catalyze the conversion of valine to leucine by chain extension and modification. We hypothesize that these genes are involved in synthesis of the aromatic amino-acid derivatives in AM-toxins from a natural aromatic amino acid by chain extension and modification.

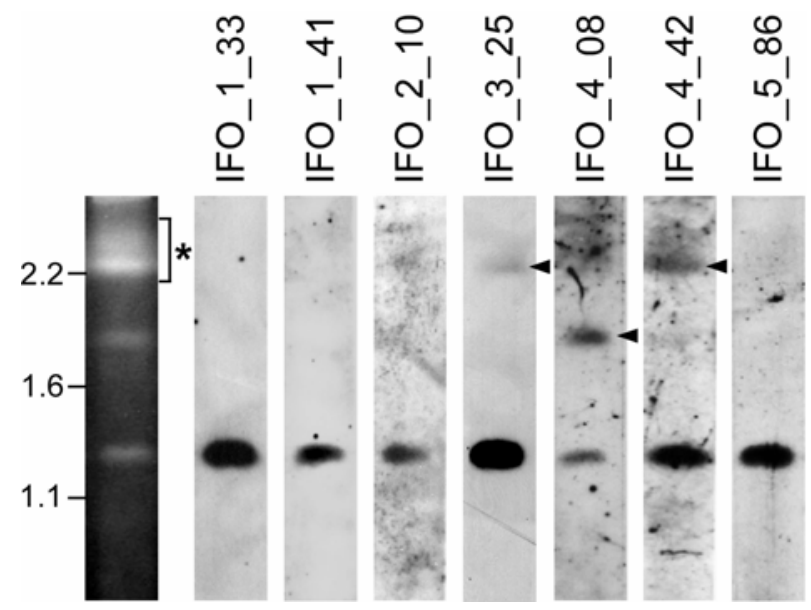

Fig. 4. Chromosomal distribution of putative housekeeping genes. Chromosome-sized DNA molecules of strain IFO8984 were separated by pulsed-field gel electrophoresis under the condition for $0.5-$ to $2.0-\mathrm{Mb}$ DNA. Under this electrophoresis condition, chromosomal DNA $>2.0 \mathrm{Mb}$ could not be resolved and were stacked at the position shown with an asterisk. The blots were hybridized with the cDNA probes. The arrowheads indicate chromosomal DNA hybridized with the probes other than the 1.4-Mb chromosome. Sizes (in megabases) of chromosomes of Saccharomyces cerevisiae are indicated on the left.
Expression analysis of genes encoded by the 1.4-Mb chromosome.

To examine the expression levels of 80 genes encoded by the 1.4-Mb chromosome, we performed real-time quantitative reverse transcription (RT)-PCR analysis of these genes under two culture conditions, in MCD and potato dextrose broth (PDB). When IFO8984 was grown in MCD and PDB at $25^{\circ} \mathrm{C}$ for 5 days, it exhibited vigorous vegetative growth in both media. The culture filtrates were treated on susceptible apple leaves. MCD cultures showed toxicity to the apple leaves, but PDB cultures showed no toxicity (Fig. 5A). Among AM-toxins I, II, and III, toxin I is the predominant species with respect both to yield and to biological activity (Johnson et al. 2000; Ueno et al. 1975). We quantified toxin I in the cultures by reverse-phase high performance liquid chromatography (HPLC) and detected it in MCD cultures $(2.2 \mu \mathrm{g} / \mathrm{ml}$ in the average of three cultures) but not in PDB culture (Fig. 5B). This result suggested that transcription of AM-toxin biosynthetic genes is induced specifically in MCD. We used these two cultures in real-time PCR analysis to assess the transcription levels of the

A

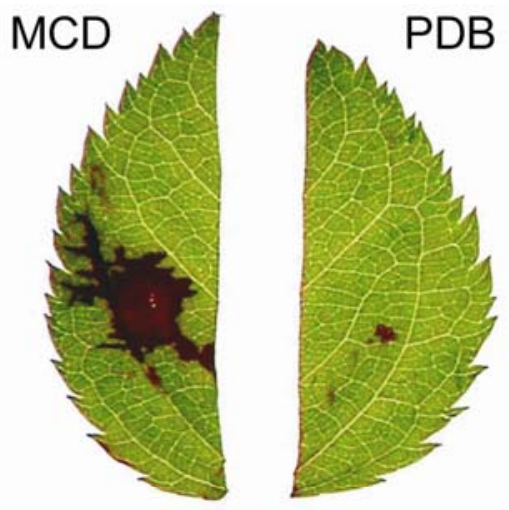

B
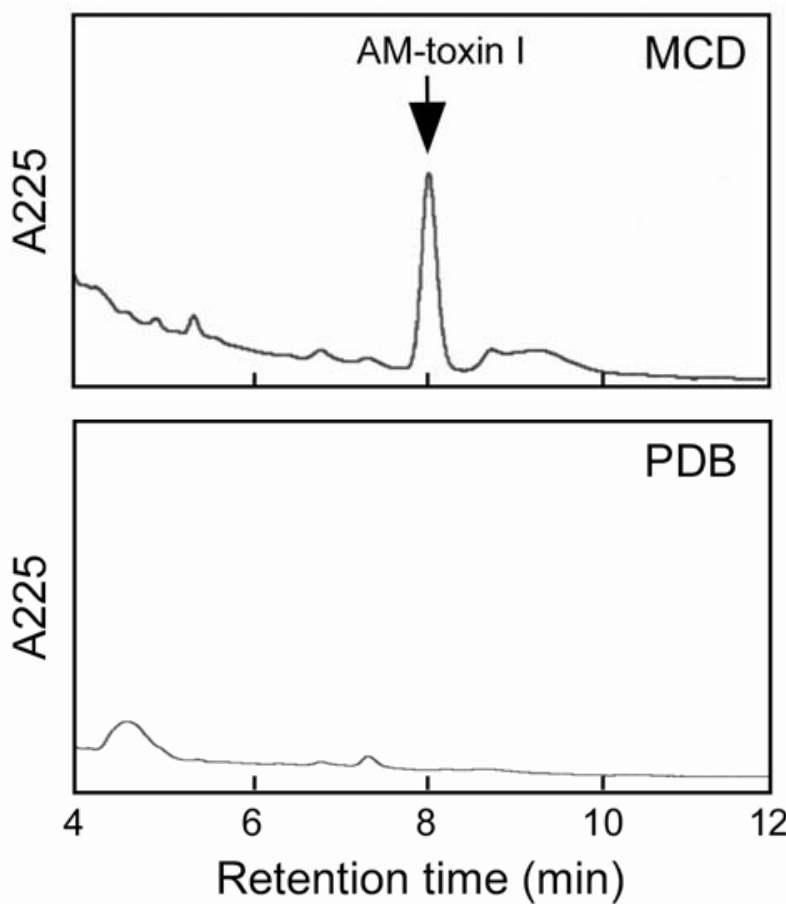

Fig. 5. AM-toxin production of strain IFO8984. A, IFO8984 was grown in modified Czapek-Dox (MCD) and potato dextrose broth (PDB) at $25^{\circ} \mathrm{C}$ for 5 days. A leaf of apple cultivar Starking was wounded slightly, was treated with culture filtrates, and was incubated at $25^{\circ} \mathrm{C}$ for $24 \mathrm{~h}$ in a moist box. B, AM-toxin I in culture filtrates was detected by reverse-phase highperformance liquid chromatography. 
1.4-Mb chromosome genes and to obtain candidates of novel AM-toxin biosynthetic genes.

Primer pairs were designed to anneal to 80 transcripts for real-time PCR analysis using cDNA templates derived from MCD and PDB cultures. The translation elongation factor 1- $\alpha$ gene $(E F 1-\alpha)$ and actin gene $(A C T)$ were used as constitutively expressed endogenous controls. Initially, we compared expression levels of these genes between MCD and PDB cultures, finding them to be similar between the two cultures. Two experiments with independently isolated RNA and subsequently synthesized cDNA samples demonstrated similar expression patterns; the mean level of expression in $\mathrm{MCD} /$ mean expression in PDB was 0.81 for $E F 1-\alpha$ or 1.32 for $A C T$. In both cultures, $E F 1-\alpha$ had higher expression levels than $A C T$; the mean level of expression of $E F 1-\alpha$ to mean expression of $A C T$ was 8.28 and 13.45 in MCD and PDB, respectively. In this study, the expression level of $E F 1-\alpha$ in MCD or PDB was used as an endogenous reference for normalization in respective cultures.

Real-time PCR analysis of the transcription levels of 80 genes in MCD and PDB showed that most of the 1.4-Mb chromosome genes were expressed at marked lower levels than those of EF1- $\alpha$ in both cultures; 76 (95\%) and 78 (98\%) genes had over 10-fold lower expression levels in MCD and PDB, respectively, and $55(69 \%)$ and $64(80 \%)$ genes had over 100-fold lower expression levels in MCD and PDB, respectively (Table 2 and Fig. 6). The selection frequency of cDNA clones encoded by the 1.4-Mb chromosome was fairly low as described. This was probably due to the fact that the genes encoded by the 1.4$\mathrm{Mb}$ chromosome are expressed at lower levels than those encoded by the other chromosomes.

The expression levels of these genes between MCD and PDB cultures were compared by real-time PCR analysis and were calculated as the mean level of expression in MCD to the mean expression in PDB. Expectedly, AMT1 and AMT2 were markedly upregulated (57.1- and 1,248.8-fold) in MCD cultures as compared with PDB cultures (Table 2). Additionally, 19 genes had expression levels over 10-fold higher in MCD cultures than in PDB cultures (Table 2). Of the 19 genes, eight (IFO_1_11, IFO_1_18, IFO_1_33, IFO_1_35, IFO_1_88, IFO_2_10, IFO_3_25, and IFO_3_84) have similarity to enzymes involved in secondary metabolism and amino-acid modification (Table 2), suggesting that these genes encode AM-toxin biosynthetic enzymes. IFO_1_33, IFO_2_10, and

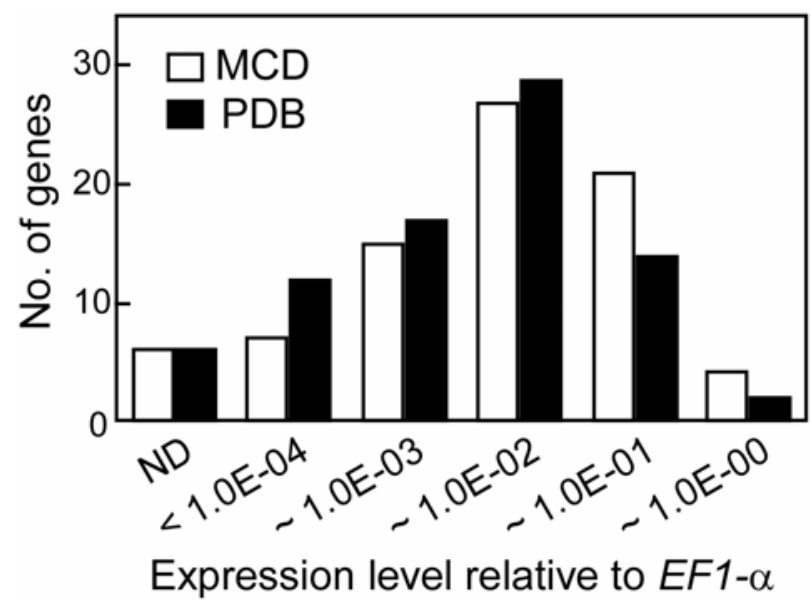

Fig. 6. The expression levels of genes encoded by the 1.4-Mb chromosome in modified Czapek-Dox (MCD) and potato dextrose broth (PDB) cultures. The expression level of each gene was quantified by real-time quantitative polymerase chain reaction and was normalized to that of EF1$\alpha$ (value $=1$ ) for each culture condition. When transcripts were not detected at significant levels, genes were classified as ND (not detected).
IFO_3_25, with similarity to leucine biosynthetic enzymes, displayed $>50$-fold induction in MCD cultures (Table 2). This result further suggests that these genes are involved in biosynthesis of the aromatic amino-acid derivatives in AM-toxins by chain extension and modification of a natural aromatic amino acid. Because IFO_1_11 has similarity to an $O$-methyltransferase involved in aflatoxin biosynthesis of $A$. parasiticus (Yu et al. 2004), it seems to be required for L- $\alpha$-amino-methoxyphenyl-valeric acid biosynthesis in AM-toxin I (Fig. 1). IFO_1_35 is predicted to encode cytochrome P450 monooxygenase, which typically modifies or customizes the peptide backbone to form a functional secondary metabolite (Keller et al. 2005). IFO_1_18 and IFO_1_88 encode nonribosomal peptide synthetase, and IFO_3_84 encodes polyketide synthase.

In less than a decade, it was shown that the genes for production of a broad range of fungal secondary metabolites are clustered (Keller et al. 2005; Walton 2000). We isolated BAC clones that contain both AMT1 and AMT2 (Y. Harimoto, M. Kodama, M. Yamamoto, H. Otani, and T. Tsuge, unpublished data). We also analyzed the presence of 19 genes upregulated in MCD cultures in isolated BAC clones and identified a clone (BAC_14) that contains 13 genes (IFO_1_11, IFO_1_18, IFO_1_33, IFO_1_35, IFO_1_44, IFO_1_57, IFO_1_88, IFO_2_10, IFO_2_48, IFO_3_25, IFO_3_84, IFO_4_61, and IFO_5_86) as well as $A M T 1$ and $A M T 2$. Of these 13 genes, eight have similarity to enzymes involved in secondary metabolism and amino-acid modification (Table 2), suggesting that this clone encodes the AM-toxin biosynthetic gene cluster.

\section{Functional analysis of IFO_1_35 and IFO_3_84.}

To assess the function of the genes that are upregulated in MCD and encoded by BAC_14 in AM-toxin biosynthesis, we made mutants of the gene encoding IFO_1_35 (cytochrome P450 monooxygenase) (Table 2). We determined the sequence of the region encoding IFO_1_35 in BAC_14 and identified an ORF that consists of three exons and encodes 486 amino acids with significant similarity to cytochrome P450 monooxygenases from fungi (Fig. 7A). Homologous recombination was employed to replace this ORF with the plasmid pGD1_35h, which contains the target gene fragment interrupted with the hygromycin B phosphotransferase gene (hph) cassette (Fig. 7A). IFO8984 was transformed with pGD1_35h, and 12 transformants were isolated. The integration mode of pGD1_35h in transformants was analyzed by PCR using primer pair hph-F and T1-35-R (Fig. 7A). The PCR amplification produced expected fragments of $1.6 \mathrm{~kb}$ in two transformants (GD1_35s-1 and GD1_35s-2) (Fig. 7B). We also analyzed the mode of integration of pGD1_35h in the transformants by DNA gel blot hybridization. Total DNA of IFO8984 and pGD1_35h transformants was digested with $S a c I$, and the blot was probed with the target gene fragment (Fig. 7A). IFO8984 had a single band of $4.3 \mathrm{~kb}$ hybridizing to the probe (Fig. 7C). In the transformants, the probe hybridized to $7.3-\mathrm{kb}$ bands, resulting from homologous integration of pGD1_35h, and also to $4.3-\mathrm{kb}$ bands (Fig. 7C), indicating that IFO8984 has at least two copies of this gene.

AM-toxin I in the cultures of the single-copy mutants was quantified by HPLC. These mutants produced smaller amounts of toxin I than IFO8984 (Fig. 7D), indicating that this gene is involved in AM-toxin biosynthesis. Thus, this gene was named AMT3. When these mutants were tested for pathogenicity to apple leaves, they preserved pathogenicity indistinguishable from the wild type (data not shown),

To disrupt the second copy of $A M T 3$, we used the vector pGD1_35n, which contains the AMT3 fragment interrupted with the neomycin phosphotransferase II gene (nptII) cassette (Fig. 7A). The single-copy mutant GD1_35s-1 was retrans- 
formed with pGD1_35n and 30 transformants were isolated. The integration mode of pGD1_35n in transformants was analyzed by PCR, using primer pair npt-F and T1-35-R (Fig. 7A). The PCR produced expected fragments of $1.7 \mathrm{~kb}$ in three transformants (GD1_35d-1 to GD1_35d-3) (Fig. 7B). Total DNA of the transformants was digested with $\mathrm{SacI}$, and the blot was probed with the AMT3 fragment (Fig. 7A). The transformants had three bands of $4.3,7.1$, and $7.3 \mathrm{~kb}$; 4.3-kb bands correspond to the wild-type $A M T 3,7.1-$ and 7.3-kb bands resulted from homologous integration of pGD1_35n and pGD1_35h, respectively (Fig. 7B). These results suggest that IFO8984 might have three copies of AMT3, and that two copies were mutated in GD1_35d transformants.

The two-copy mutants produced smaller amounts of AMtoxin than the wild type and AMT3 single-copy mutants (Fig. 7D). However, these mutants caused lesions on apple leaves, as did the wild type (data not shown). AM-toxin I is known to show specific toxicity on susceptible apple leaves at approximately $50 \mathrm{ng} / \mathrm{ml}$ (Kohmoto et al. 1977). Thus, it is likely that the amount of toxin produced by the two-copy mutants during the infection process is still enough for expressing pathogenicity.
We also made mutants of the gene encoding IFO_3_84 (polyketide synthase) (Table 2). We determined the sequence of the region encoding IFO_3_84 in BAC_14 and identified an ORF. This ORF consists of three exons and encodes 261 amino acids with significant similarity to thioesterase domains of polyketide synthases or nonribosomal peptide synthetases (Fig. 8A). Homologous recombination was employed to replace this ORF in IFO8984 with the plasmid pGD3_84h, which contains the target gene fragment interrupted with the $h p h$ cassette (Fig. 8A). We analyzed the integration mode of pGD3_84h in 12 transformants by PCR, using primer pair T3-84-F and hph$\mathrm{R}$ (Fig. 8A), and detected expected fragments of $2.0 \mathrm{~kb}$ in four transformants (GD3_84s-1 to GD3_84s-4) (Fig. 8B). Total DNA of the transformants was digested with $P v u \mathrm{II}$, and the blot was probed with the target gene fragment (Fig. 8A). IFO8984 had a single 2.9-kb band hybridizing to the probe, and the transformants had 5.9-kb bands, resulting from homologous integration of pGD3_84h, and also 2.9-kb bands (Fig. 8C). These results indicate that IFO8984 also has multiple copies of this gene.

These mutants produced smaller amounts of toxin I than IFO8984 (Fig. 8D), indicating that this gene is also involved in
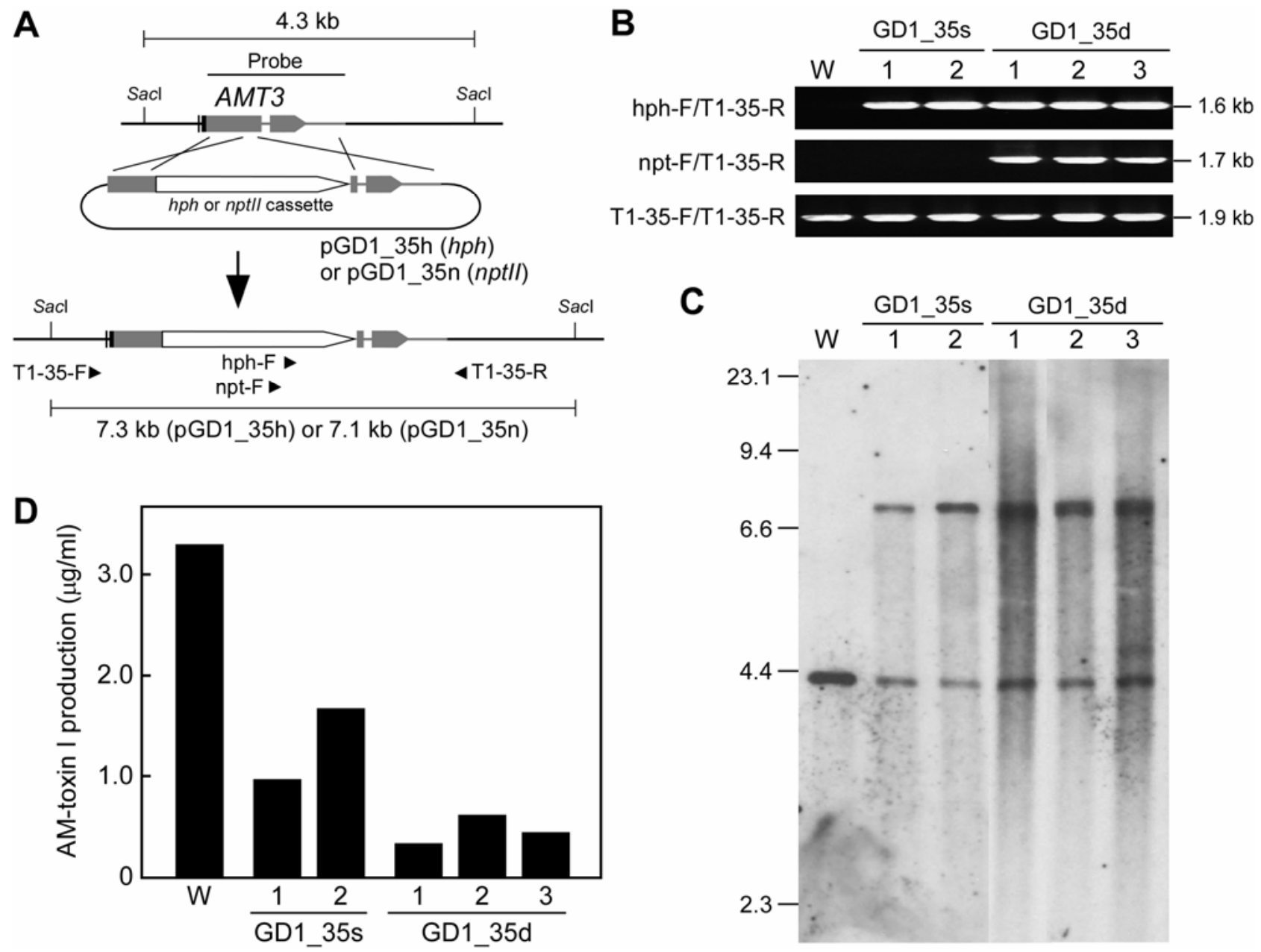

Fig. 7. Transformation-mediated disruption of IFO_1_35 (AMT3). A, Structure of the AMT3 locus before and after homologous integration of the targeting vectors pGD1_35h and pGD1_35n. The targeting vectors pGD1_35h and pGD1_35n were made by cloning $h p h$ and $n p t I I$ cassettes, respectively, within the AMT3 fragment. The arrowheads denote the orientation and location of oligonucleotide primers used in polymerase chain reaciton (PCR) experiments. B, PCR analysis of transformants. Total DNA of each strain was used as a template for PCR with primer pairs hph-F and T1-35-R, npt-F and T1-35-R, and T135-F and T1-35-R. The PCR products were electrophoresed in a 1.2\% agarose gel. W = wild-type strain IFO8984; GD1_35s-1 and GD1_35s-2 = AMT3 single-copy mutants; GD1_35d-1 to GD1_35d-3 = AMT3 double-copy mutants made from GD1_35s-1. C, DNA gel blot analysis of transformants. Total DNA ( $1 \mu \mathrm{g}$ ) of each strain was digested with $\mathrm{SacI}$ and fractionated in a $0.8 \%$ agarose gel. The blot was probed with the AMT3 fragment. Sizes (in kilobases) of marker DNA fragments (HindIII-digested $\lambda$ DNA) are indicated on the left. D, AM-toxin production of transformants. AM-toxin I in culture filtrates was detected by reverse-phase high-performance liquid chromatography. Each value represents the average of two determinations. 

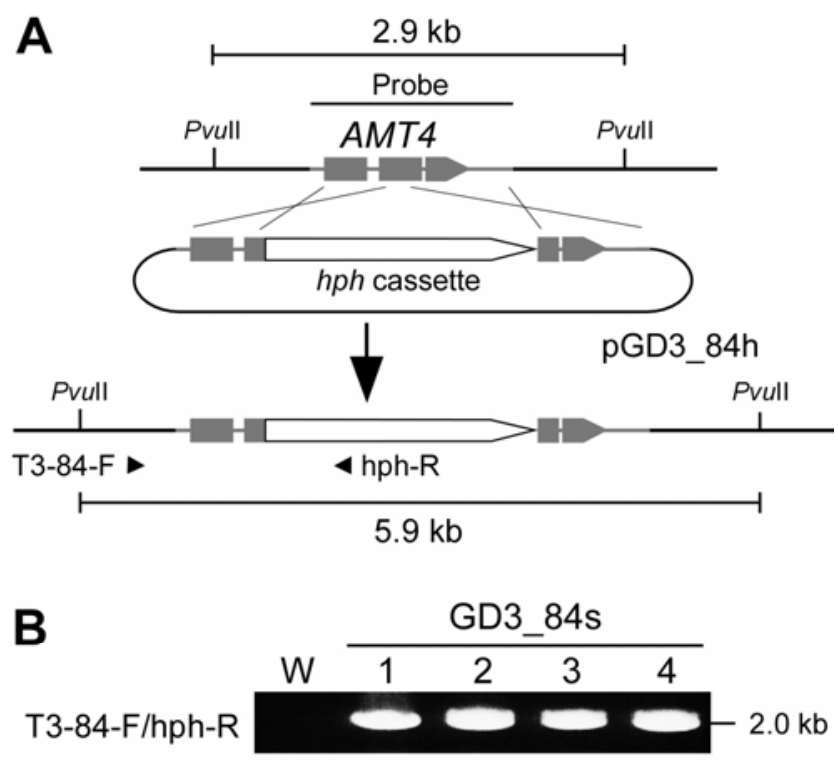

C
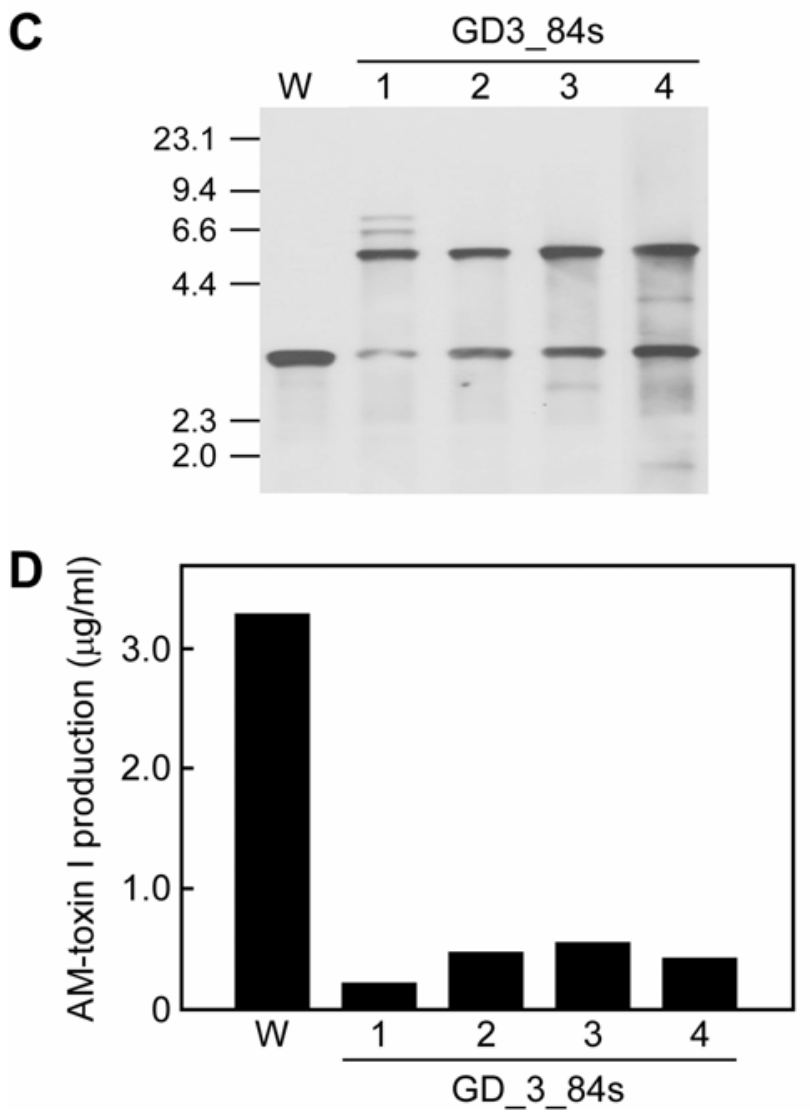

Fig. 8. Transformation-mediated disruption of IFO_3_84 (AMT4). A, Structure of the AMT4 locus before and after homologous integration of the targeting vectors pGD3_84h. The targeting vector pGD3_84h was made by cloning the $h p h$ cassette within the AMT4 fragment. The arrowheads denote the orientation and location of oligonucleotide primers used in polymerase chain reaction (PCR) experiments. B, PCR analysis of transformants. Total DNA of each strain was used as a template for PCR with primer pairs T1-35-F and hph-R. The PCR products were electrophoresed in a $1.2 \%$ agarose gel. W = wild-type strain IFO8984; GD3_84s-1 to GD3_84s-4 = AMT4 single-copy mutants. C, DNA gel blot analysis of transformants. Total DNA $(1 \mu \mathrm{g})$ of each strain was digested with $P v u \mathrm{II}$ and was fractionated in a $0.8 \%$ agarose gel. The blot was probed with the AMT4 fragment. Sizes (in kb) of marker DNA fragments (HindIII-digested $\lambda$ DNA) are indicated on the left. D, AM-toxin production of transformants. AM-toxin I in culture filtrates was detected by reverse-phase highperformance liquid chromatography. Each value represents the average of two determinations.
AM-toxin biosynthesis. This gene was named AMT4. These mutants were still pathogenic and indistinguishable from the wild-type strain (data not shown). The wild-type and AMT3 or AMT4 mutant strains were indistinguishable in vegetative growth and conidiation (data not shown).

IFO8984 have multiple, functional copies of AMT3 and $A M T 4$. We previously found that the apple pathotype strains also have two or three copies of $A M T 1$ and $A M T 2$ (Ito et al. 2004; Johnson et al. 2000). We assessed the copy numbers of AMT2, AMT3, and AMT4 in IFO8984 by DNA gel blot analysis with several restriction enzymes. This analysis could not detect restriction fragment length polymorphisms among different copies of these genes (data not shown). Thus, IFO8984 seems to have multiple sets of the $A M T$ gene clusters that all have similar structure and reside on the $1.4-\mathrm{Mb}$ chromosome.

We isolated host-specific toxin biosynthetic genes from five pathotypes (apple, Japanese pear, strawberry, tangerine, and tomato) of A. alternata and found that four pathotypes, all except for the tomato pathotype, have multiple copies of the toxin biosynthetic genes (Akagi et al. 2005; Hatta et al. 2002; Ito et al. 2004; Johnson et al. 2000; Masunaka et al. 2000; Ruswandi et al. 2005; Tanaka and Tsuge 2000; Tanaka et al. 1999; Yamagishi et al. 2006). Thus, the genomic regions controlling biosynthesis of host-specific toxins in A. alternata pathogens are not simple genetic loci but, instead, are large, complex regions of DNA. TOX2 locus controlling HC-toxin production in Cochliobolus carbonum is also a complex locus, extending over $>540 \mathrm{~kb}$ and containing multiple copies of multiple genes (Ann and Walton 1996).

Our data strongly suggest that BAC clone BAC_14, which encodes genes upregulated in MCD, contains an AM-toxin biosynthetic gene cluster. Further molecular analysis of BAC_14 and the 1.4-Mb chromosome is in progress to identify the entire gene cluster and to characterize the structure and function of the $\mathrm{CD}$ chromosome.

\section{MATERIALS AND METHODS}

\section{Fungal strains.}

Six strains of the apple pathotype were used for analyses of electrophoretic karyotypes and chromosomal distribution of $A M T$ genes, and strain IFO8984 was used for EST analysis of its 1.4-Mb chromosome encoding AMT genes (Table 1). Seven strains from the other six pathotypes and nonpathogenic $A$. alternata were also used in this study (Table 1). Strains were routinely maintained on potato dextrose agar (Difco, Detroit).

Assay for AM-toxin production and pathogenicity.

IFO 8984 was grown statically in $30 \mathrm{ml}$ of MCD $(1.5 \%$ glucose, $1.5 \%$ sucrose, $0.5 \%$ peptone, $0.5 \%$ yeast extract, $0.1 \%$ $\mathrm{KH}_{2} \mathrm{PO}_{4}, 0.05 \% \mathrm{MgSO}_{4} \cdot 7 \mathrm{H}_{2} \mathrm{O}, 0.05 \% \mathrm{KCl}, 0.001 \% \mathrm{FeSO}_{4} \cdot$ $7 \mathrm{H}_{2} \mathrm{O}$ ) or PDB (Difco) in $100-\mathrm{ml}$ Erlenmeyer flasks at $25^{\circ} \mathrm{C}$ for 5 days. To assay for toxicity of culture filtrates, leaves of apple cultivar Starking were wounded slightly, were treated with culture filtrates, and were incubated in a moist box at $25^{\circ} \mathrm{C}$ for 24 h. AM-toxin I in culture filtrates was quantified by reverse-phase HPLC (Johnson et al. 2000). Culture filtrate $(20 \mu \mathrm{l})$ was injected into a Develosil ODS-7 column (Nomura Chemical, Seto, Japan) equipped with a LC-10AT pump (Shimadzu Corporation, Kyoto, Japan) and was analyzed with SPD-10A UV-VIS detector (Shimadzu Corporation). Running solvent was $45 \%$ of acetonitrile at a flow rate of $1.0 \mathrm{ml}$ per min.

\section{Nucleic acid manipulation.}

Total DNA from A. alternata was isolated as previously described (Tanaka et al. 1999). Restriction enzyme digestion of fungal genomic DNA and fractionation in agarose gels were 
performed by the standard methods (Sambrook and Russell 2001). Fractionated DNA was transferred to Hybond $\mathrm{N}^{+}$nylon membranes (GE Healthcare Bio-Sciences, Piscataway, NJ, U.S.A.) and was subjected to hybridization and detection, using Gene Images random-prime labeling and detection reagents (GE Healthcare Bio-Sciences) according to the manufacturer's instructions.

For isolation of total RNA from fungal tissues, strain IFO8984 was grown statically in $30 \mathrm{ml}$ of MCD or PDB in $100-\mathrm{ml}$ Erlenmeyer flasks at $25^{\circ} \mathrm{C}$ for 5 days. The resulting mycelia were collected, then ground in liquid nitrogen in a mortar with a pestle. Total RNA was extracted from powdered mycelia as previously described (Tanaka et al. 1999). Poly(A) ${ }^{+}$ RNA was isolated from total RNA with the Oligotex-dT30 super mRNA purification kit (Takara Bio, Ohtsu, Japan) according to the manufacturer's instructions.

\section{PFGE.}

Agarose plugs containing chromosome-sized DNA molecules were prepared by embedding fungal protoplasts in certified low-melt agarose gels (Bio-Rad Laboratories, Richmond, CA, U.S.A.) as previously described (Adachi et al. 1996). PFGE was carried out in a contour-clamped homogeneous electric field (CHEF) apparatus (CHEF-DRII; Bio-Rad Laboratories), using $0.5 \times$ tris-borate-EDTA (Sambrook and Russell 2001) at $8^{\circ} \mathrm{C}$ in $0.8 \%$ pulsed-field certified agarose gels (Bio-Rad Laboratories) under conditions previously described (Hatta et al. 2002). After PFGE, the gels were stained with ethidium bromide for $30 \mathrm{~min}$ and destained in distilled water for $30 \mathrm{~min}$. DNA gel blotting was performed as previously described (Adachi et al. 1996). Gene Images random-prime labeling and detection reagents were used for labeling of probes and hybridization signal detection. The DIG-labeled telomeric repeat [(TTAGGG $)_{8}$ ] probe used in hybridization experiments was synthesized by Japan Gene Research Laboratories (Sendai, Japan), and the DIG luminescent detection kit (Roche Diagnostic, Indianapolis, IN, U.S.A.) was used for signal detection.

To collect 1.4-Mb chromosome DNA of strain IFO8984, PFGE was carried out in the CHEF-DRII apparatus at $8^{\circ} \mathrm{C}$ in $0.8 \%$ certified low-melt agarose gels under the following electrophoretic conditions: duration/voltage/switching time $(\mathrm{h} / \mathrm{V} / \mathrm{s})$ 20:180:120 and 20:180:180. After staining the gel with ethidium bromide, a piece of agarose containing the $1.4-\mathrm{Mb}$ DNA was excised and treated with GELase (Epicentre, Madison, WI, U.S.A.) according to the manufacturer's instructions. Recovered DNA was used as a probe for hybridization experiments.

\section{cDNA library.}

The cDNA library was prepared in a plasmid pBluescript II SK+ (Stratagene, La Jolla, CA, U.S.A.), using the cDNA synthesis kit (Stratagene) according to the manufacturer's instructions. Poly $(\mathrm{A})^{+}$RNA was reverse-transcribed with an oligo(dT) primer, and double-stranded cDNA was synthesized. The cDNA was unidirectionally cloned into the EcoRI-XhoI site of pBluescript II SK+ (with the $3^{\prime}$ poly[A] tails close to the XhoI site).

Ligated plasmids were transformed by electroporation into E. coli ElectroMAX DH10B (Invitrogen, San Diego, CA, U.S.A.), using an electroporation apparatus, GenePulser (BioRad Laboratories), according to the manufacturer's instructions, and E. coli cells were plated on LB agar plates supplemented with $50 \mu \mathrm{g}$ of ampicillin per milliliter (Sigma, St. Louis). A total of 200 colonies were picked with sterilized toothpicks and lined up on an ampicillin-LB plate $(9.5-\mathrm{cm}$ round). Raised colonies were blotted onto Hybond $\mathrm{N}^{+}$nylon membranes by the standard method (Sambrook and Russell
2001). A total of 40,980 clones were screened by colony hybridization with the $1.4-\mathrm{Mb}$ chromosomal DNA probe. Gene Images random-prime labeling and detection reagents were used for probe labeling and signal detection.

\section{BAC library.}

A genomic BAC library of IFO8984 was constructed with a $\mathrm{BAC}$ vector pcc1BAC (Epicentre). Chromosome-sized DNA molecules in agarose plugs was partially digested with Sau3AI (Takara Bio) and was fractionated in a $1.0 \%$ certified low-melt agarose gel in the CHEF-DRII as previously described (Hatta et al. 2006). A piece of agarose containing DNA fragments of about $150 \mathrm{~kb}$ was excised and treated with $\beta$-agarase (New England BioLabs, Ipswich, MA, U.S.A.) according to the manufacturer's instructions. Recovered DNA was ligated with BamHI-digested, dephosphorylated pcc1BAC using T4 DNA ligase (Takara Bio). Ligation products were desalted by the drop-dialysis method (Sambrook and Russell 2001) and were transformed by electroporation into $E$. coli ElectroMAX DH10B using an electroporation apparatus, GenePulser. A total of 1,517 colonies were obtained and used for screening clones containing the 1.4-Mb chromosome DNA. The average insert size in the 16 clones analyzed was $102 \mathrm{~kb}$, and the 1,517 clones were expected to contain a total of $155 \mathrm{Mb}$, that is, about fivefold the A. alternata genome size (about $30 \mathrm{Mb}$ ). BAC clones of IFO8984 were screened by colony hybridization with the 1.4$\mathrm{Mb}$ chromosomal DNA probe, and 78 positive clones that contain the chromosome DNA were identified.

\section{DNA sequencing and analysis.}

Plasmids containing cDNA were isolated from E. coli by cellular lysis and plasmid DNA purification using the FlexiPrep kit (GE Healthcare Bio-Sciences). DNA sequences were determined with the BigDye terminator v3.1 cycle sequencing kit (Applied Biosystems, Foster City, CA, U.S.A.) and an automated fluorescent sequencer (ABI PRISM 3100 genetic analyzer; Applied Biosystems). Single-pass sequencing was performed from the $3^{\prime}$ end of the cDNA (corresponding to the 5 ', nonpoly(A) tail end of the mRNA) using a T3 primer. The resultant sequences were processed manually to remove vector sequences and low-quality bases. The EST sequences were assembled into overlapping contigs and singletons with a DNAsis Pro ver. 2.2 program (Hitachi Software Engineering, Yokohama, Japan), using a minimum match percentage of $90 \%$ for 30 overlapping bases.

The BLASTX algorithms at NCBI were used to identify sequences in the nonredundant databases from NCBI (Altschul et al. 1997). A match was considered significant if the $E$ value was less than $1 \mathrm{E}-5$, and for this analysis only the most significant matches were examined. Sequences were grouped on the basis of their most likely function following the general rules developed for MIPS (Mewes et al. 1997, 2002). Additional database searches were performed with the cDNA clones using the Fungal Genome Initiative databases at the Broad Institute website and the Eukaryotic Genomics databases at the DOE Joint Genome Institute website. Searches were performed using the BLASTX algorithms available at the respective websites, using a cutoff $E$ value of $1 \mathrm{E}-5$. Alignment of nucleotide and amino-acid sequences was made with the CLUSTAL W program (Thompson et al. 1994).

\section{Real-time quantitative RT-PCR.}

Total RNA used for real-time PCR analysis was prepared from fungal tissue grown in MCD and PDB as described above. The single-stranded cDNA was synthesized from total RNA with an oligo(dT) primer, using the First-strand cDNA synthesis kit for RT-PCR (Roche Diagnostic), and was used as 
template for real-time PCR. PCR primers were designed to amplify target cDNA fragments of 200 to $250 \mathrm{bp}$ with a primer design software in DNAsis Pro ver. 2.2. Primers were also designed for the EF1- $\alpha$ and actin genes as constitutively expressed endogenous controls.

Reactions were performed in a LightCycler quick system 350S (Roche Diagnostic) in 20- $\mu$ l glass capillary tubes. Each reaction $(20 \mu \mathrm{l})$ consisted of $10 \mu \mathrm{l}$ of QuantiTect SYBR-green PCR master mix (Qiagen, Nenlo, The Netherlands), $0.5 \mu \mathrm{M}$ each of forward and reverse primers, and cDNA template. Reaction mixtures were heated to $94^{\circ} \mathrm{C}$ for $15 \mathrm{~min}$, followed by 50 cycles of $94^{\circ} \mathrm{C}$ for $15 \mathrm{~s}, 55^{\circ} \mathrm{C}$ for $30 \mathrm{~s}, 72^{\circ} \mathrm{C}$ for $25 \mathrm{~s}$, and $78^{\circ} \mathrm{C}$ for $5 \mathrm{~s}$. A melting curve was generated for each sample at the end of each run, to serve as an assessment of the purity of the amplified products. After reactions, samples were electrophoresed in agarose gels to verify amplification of the target fragments.

Expression of each gene was measured twice with independently isolated RNA and subsequently synthesized cDNA samples. To verify that the efficiencies of the target (cDNAs) and endogenous control reactions were approximately equal, we performed reactions with serial dilutions of cDNA as templates. The threshold cycle was calculated with LightCycler software ver. 3.5 (Roche Diagnostic), using the second-derivative-maximum method (LightCycler operator's manual ver. 3.5; Roche Diagnostic), and the expression level of each gene was calculated from the gene-specific standard curve. The expression level of each target was normalized to that of EF1- $\alpha$ (value $=1$ ) for each culture condition.

\section{Plasmid construction and fungal transformation.}

The AMT3 disruption vectors pGD1_35h and pGD1_35n (Fig. 7A) were constructed by cloning the $h p h$ and nptII cassettes, respectively, within AMT3 with the In-Fusion dry-down PCR cloning kit (Clontech, Mountain View, CA, U.S.A). The 1.8-kb region of $A M T 3$ was amplified from BAC_14 DNA by PCR, using primer pair AMT3-F (5'-GAG AAC TTG TCT ATC ACC CCT C-3') and AMT3-R (5'-ATA GGT GCG TTG GGT ACG CA-3'), and was cloned in pBluescript II SK+ to make pAMT3. To make pGD1_35h and pGD1-35n, linearized pAMT3 was made by inverse PCR using primer pair Dis1_35F (5'-CGA AAA GGG ATA TCT GGG GCT T-3') and Dis1_35R (5'-CCT CAC TCT TCT GTT GCC GTT T-3'). These primers correspond to sequences in the desired site of the $h p h$ or $n p t I I$ cassette insertion in AMT3. The hph and nptII cassettes, which contain hph and nptII fused to the Aspergillus nidulans trpC promoter and terminator, were amplified from pSH75 (Kimura and Tsuge 1993) and pII99 (Namiki et al. 2001), respectively, by PCR, using the primer pair 1_35-PtrpC (5'-CAA CAG AAG AGT GAG GAT GCC AGT TGT TCC AGT GAT CTT$\left.3^{\prime}\right)$ and 1_35-TtrpC (5'-CAG ATA TCC CTT TTC GAG TGT ACC TGT GCA TTC TGG G-3'). These primers have 16 bases (underlined) identical to sequences at the ends of the linearized pAMT3. The linearlized plasmids and the hph or $n p t I I$ cassette were subjected to the in-fusion cloning reaction, and plasmids were transformed into $E$. coli fusion-blue competent cells (Clontech) according to the manufacturer's instructions.

The AMT4 disruption vector pGD3_84h (Fig. 8A) was constructed by cloning the $h p h$ cassette within AMT4 by the same method. The 1.2-kb region of AMT4 was amplified from BAC_14 DNA by PCR, using primer pair AMT4-F (5'- CTT TCG TAG ACC TTG TGC AAT CTA -3') and AMT4-R (5'CGA AGA AGG CTG CAT CGA GC $-3^{\prime}$ ), and was cloned in pBluescript II SK+ to make pAMT4. Primer pair Dis3_84F (5'GAC GAT GTT CCA GAC TGT ATG C -3') and Dis3_84R (5'TGG GAC AAT AGG TCC GTT TGC AA -3') was used for preparation of linearized pAMT4, and primer pair 3_84-PtrpC
(5'- CGG ACC TAT TGT CCC AAT GCC AGT TGT TCC AGT GAT CTT $\left.-3^{\prime}\right)$ and 3_84-TtrpC (5'- AGT CTG GAA CAT CGT CAG TGT ACC TGT GCA TTC TGG G -3') was used for amplification of the $h p h$ cassette from pSH75. These primers have 16 bases (underlined) identical to sequences at the ends of the linearized IFO_3_84 plasmid.

Protoplast preparation and transformation of A. alternata were performed by the methods previously described (Ito et al. 2004). Transformants carrying hph or nptII were selected on regeneration media containing hygromycin B (Wako Pure Chemicals, Osaka, Japan) at $100 \mu \mathrm{g} \mathrm{ml}^{-1}$ or geneticin (Gibco BRL, Life Technology, Gaithersburg, MD, U.S.A.) at $400 \mu \mathrm{g}$ $\mathrm{ml}^{-1}$, respectively (Ito et al. 2004).

The integration mode of transformation vectors in transformants was analyzed by PCR, using primers hph-F (5'-GCA CTC GTC CGA GGG CAA AG-3'), hph-R (5'-CGA AGC TGA AAG CAC GAG AT-3'), npt-F (5'-TCG CAG CGC ATC GCC TTC TA-3'), T1-35-F (5'-TGT CAA CTA TGG GCT TCC TGA CTC-3'), T1-35-R (5'-GGC AGC TGC TCA CCA TTG GAC A-3'), and T3-84-F (5'-CCT GCC GTC TGC TTG TTC GCG-3') (Figs. 7A and 8A).

\section{ACKNOWLEDGMENTS}

We are grateful to K. Akimitsu, H. Yoshioka, K. Kawakita, and N. Doke for valuable suggestions and to N. Nakazawa, F. Nakatani, Y. Sato, and M. Kusaba for providing fungal strains. This work was supported by Special Coordination Funds for Promoting Sciences from the Ministry of Education, Science, Sports, Culture and Technology of Japan and grants-in-aids from Japanese Society for Promotion of Sciences.

\section{LITERATURE CITED}

Adachi, Y., Watanabe, H., and Tsuge, T. 1996. Relationships between genetic polymorphisms and fungicide resistance within Alternaria alternata. Phytopathology 86:1248-1254.

Akagi, Y., Akamatsu, H., Yamamoto, M., Tsuge, T., Otani, H., and Kodama, M. 2005. Characterization of the genomic region, controlling biosynthesis of host-specific AAL-toxins, on the conditionally dispensable chromosome of the tomato pathotype of Alternaria alternata. Fungal Genet. Newsl. 52:188.

Akamatsu, H., Taga, M., Kodama, M., Johnson, R., Otani, H., and Kohmoto, K. 1999. Molecular karyotypes for Alternaria plant pathogens known to produce host-specific toxins. Curr. Genet. 35:647-656.

Altschul, S. F., Madden, T. L., Schaffer, A. A., Zhang, J., Zhang, Z., Miller, W., and Lipman, D. J. 1997. Gapped BLAST and PSI-BLAST: A new generation of protein database search programs. Nucleic Acids Res. 25:3389-3402.

Ann, J.-H., and Walton, J. D. 1996. Chromosomal organization of TOX2, a complex locus controlling host-selective toxin biosynthesis in Cochliobolus carbonum. Plant Cell 8:887-897.

Cane, D. E., and Kang, I. 2000. Aristolochene synthase: Purification, molecular cloning, high-level expression in Escherichia coli, and characterization of the Aspergillus terreus cyclase. Arch. Biochem. Biophys. 376:354-364.

Covert, S. F. 1998. Supernumerary chromosomes in filamentous fungi. Curr. Genet. 33:311-319.

Covert, S. F., Enkerli, J., Miao, V. P., and VanEtten, H. D. 1996. A gene for maackiain detoxification from a dispensable chromosome of Nectria haematococca. Mol. Gen. Genet. 251:397-406.

Dean, R. A., Talbot, N. J., Ebbole, D. J., Farman, M. L., Mitchell, T. K., Orbach, M. J., Thon, M., Kulkarni, R., Xu, J. R., Pan, H., Read, N. D., Lee, Y. H., Carbone, I., Brown, D., Oh, Y. Y., Donofrio, N., Jeong, J. S., Soanes, D. M., Djonovic, S., Kolomiets, E., Rehmeyer, C., Li, W., Harding, M., Kim, S., Lebrun, M. H., Bohnert, H., Coughlan, S., Butler, J., Calvo, S., Ma, L. J., Nicol, R., Purcell, S., Nusbaum, C., Galagan, J. E., and Birren, B. W. 2005. The genome sequence of the rice blast fungus Magnaporthe grisea. Nature 434:980-986.

Enkerli, J., Bhatt, G., and Covert, S. F. 1997. Nht1, a transposable element cloned from a dispensable chromosome in Nectria haematococca. Mol. Plant-Microbe Interact. 10:742-749.

Fatica, A., and Tollervey, D. 2002. Making ribosomes. Curr. Opin. Cell Biol. 14:313-318.

Filajdić, N., and Sutton, T. B. 1991. Identification and distribution of $A l$ - 
ternaria mali on apples in North Carolina and susceptibility of different varieties of apples to Alternaria blotch. Plant Dis. 75:1045-1048.

Gangloff, S. P., Marguet, D., and Lauquin, G. J. 1990. Molecular cloning of the yeast mitochondrial aconitase gene $(A C O 1)$ and evidence of a synergistic regulation of expression by glucose plus glutamate. Mol. Cell. Biol. 10:3551-3561.

Han, Y., Liu, X., Benny, U., Kistler, H. C., and VanEtten, H. D. 2001. Genes determining pathogenicity to pea are clustered on a supernumerary chromosome in the fungal plant pathogen Nectria haematococca. Plant J. 25:305-314.

Hartmann, M., Heinrich, G., and Braus, G., H. 2001. Regulative fine-tuning of the two novel DAHP isoenzymes aroFp and aroGp of the filamentous fungus Aspergillus nidulans. Arch. Microbiol. 175:112-121.

Hatta, R., Ito, K., Hosaki, Y., Tanaka, T., Tanaka, A., Yamamoto, M. Akimitsu, K., and Tsuge, T. 2002. A conditionally dispensable chromosome controls host-specific pathogenicity in the fungal plant pathogen Alternaria alternata. Genetics 161:59-70.

Hatta, R., Shinjo, A., Ruswandi, S., Kitani, K., Yamamoto, M., Akimitsu, K., and Tsuge, T. 2006. DNA transposon fossils present on the conditionally dispensable chromosome controlling AF-toxin biosynthesis and pathogenicity of Alternaria alternata. J. Gen. Plant Pathol. 72:210-219.

Ito, K., Tanaka, T., Hatta, R., Yamamoto, M., Akimitsu. K., and Tsuge, T. 2004. Dissection of the host range of the fungal plant pathogen Alternaria alternata by modification of secondary metabolism. Mol. Microbiol. 52:399-411.

Johnson, R. D., Johnson, L., Itoh, Y., Kodama, M., Otani, H., and Kohmoto, K. 2000. Cloning and characterization of a cyclic peptide synthetase gene from Alternaria alternata apple pathotype whose product is involved in AM-toxin synthesis and pathogenicity. Mol. Plant-Microbe Interact. 13:742-753.

Johnson, L., Johnson, R. D., Akamatsu, H., Salamiah, A., Otani, H., Kohmoto, K., and Kodama, M. 2001. Spontaneous loss of a conditionally dispensable chromosome from Alternaria alternata apple pathotype leads to loss of toxin production and pathogenicity. Curr. Genet. 40:65-72.

Kämper, J., Kahmann, R., Bölker, M., Ma, L. J., Brefort, T., Saville, B. J., Banuett, F., Kronstad, J. W. , Gold, S. E., Müller, O., Perlin, M. H., Wösten, H. A., de Vries, R., Ruiz-Herrera, J., Reynaga-Peña, C. G., Snetselaar, K., McCann, M., Pérez-Martín, J., Feldbrügge, M., Basse, C. W., Steinberg, G., Ibeas, J. I., Holloman, W., Guzman, P., Farman, M., Stajich, J. E., Sentandreu, R., González-Prieto, J. M., Kennell, J. C., Molina, L., Schirawski, J., Mendoza-Mendoza, A., Greilinger, D., Münch, K., Rössel, N., Scherer, M., Vraneš, M., Ladendorf, O., Vincon, V., Fuchs, U., Sandrock, B., Meng, S., Ho, E. C., Cahill, M. J., Boyce, K. J., Klose, J., Klosterman, S. J., Deelstra, H. J., Ortiz-Castellanos, L., Li, W., Sanchez-Alonso, P., Schreier, P. H., Häuser-Hahn, I., Vaupel, M., Koopmann, E., Friedrich, G., Voss, H., Schlüter, T., Margolis, J., Platt, D., Swimmer, C., Gnirke, A., Chen, F., Vysotskaia, V., Mannhaupt, G., Güldener, U., Munsterkötter, M., Haase, D., Oesterheld, M., Mewes, H. W., Mauceli, E. W., DeCaprio, D., Wade, C. M., Butler, J., Young, S., Jaffe, D. B., Calvo, S., Nusbaum, C., Galagan, J., and Birren, B. W. 2006. Insights from the genome of the biotrophic fungal plant pathogen Ustilago maydis. Nature 444:97-101.

Kawamura, C., Tsujimoto, T., and Tsuge, T. 1999. Targeted disruption of a melanin biosynthesis gene affects conidial development and UV tolerance in the Japanese pear pathotype of Alternaria alternata. Mol. PlantMicrobe Interact. 12:59-63.

Keller, N. P., Turner, G., and Bennett, J. W. 2005. Fungal secondary metabolism-Biochemistry to genomics. Nature Rev. Microbiol. 3:937947

Kimura, N., and Tsuge, T. 1993. Gene cluster involved in melanin biosynthesis of the filamentous fungus Alternaria alternata. J. Bacteriol. 175:4427-4435

Kistler, H. C., Meinhardt, L. W., and Benny, U. 1996. Mutants of Nectria haematococca created by site-directed chromosome breakage are greatly reduced in virulence toward pea. Mol. Plant-Microbe Interact. 9:804-809.

Kohlhaw, G. B. 2003. Leucine biosynthesis in fungi: Entering metabolism through the back door. Microbiol. Mol. Biol. Rev. 67:1-15.

Kohmoto, K., Taniguchi, T., and Nishimura, S. 1977. Correlation between the susceptibility of apple cultivars to Alternaria mali and their sensitivity to AM-toxin I. Ann. Phytopathol. Soc. Jpn. 43:65-68.

Kohmoto, K., Otani, H., and Tsuge, T. 1995. Alternaria alternata pathogens. Pages 51-63 in: Pathogenesis and Host Specificity in Plant Disease: Histopathological Biochemical, Genetic and Molecular Bases, Vol. 2. Eukaryotes. K. Kohmoto, U. S. Singh, and R. P. Singh, eds. Pergamon, Oxford, U.K.

Kroken, S. Glass, N. L. Taylor, J. W. Yoder, O. C., and Turgeon, B. G. 2003. Phylogenomic analysis of type I polyketide synthase genes in pathogenic and saprobic ascomycetes. Proc. Natl. Acad. Sci. U.S.A. 100:15670-15675.
Lee, B. N., Kroken, S., Chou, D. Y. T., Robbertse, B., Yoder, O. C., and Turgeon, B. G. 2005. Functional analysis of all nonribosomal peptide synthetases in Cochliobolus heterostrophus reveals a factor, NPS6, involved in virulence and resistance to oxidative stress. Eukaryot. Cell 4:545-555.

Markham, J. E., and Hille, J. 2001. Host-selective toxins as agents of cell death in plant-fungus interactions. Mol. Plant Pathol. 2:229-240.

Masunaka, A., Tanaka, A., Tsuge, T., Peever, T. L., Timmer, L. W. Yamamoto, H., Yamamoto, M., and Akimitsu, K. 2000. Distribution and characterization of $A K T$ homologs in the tangerine pathotype of Alternaria alternata. Phytopathology 90:762-768.

Masunaka, A., Ohtani, K., Peever, T. L., Timmer, L. W., Tsuge, T., Yamamoto, M., Yamamoto, H., Akimitsu, K. 2005. An isolate of Alternaria alternata that is pathogenic to both tangerines and rough lemon and produces two host-selective toxins, ACT- and ACR-toxins. Phytopathology 95:241-247.

Mewes, H. W., Albermann, K., Heumann, K., Liebl, S., and Pfeiffer, F. 1997. MIPS: A database for protein sequences, homology data and yeast genome information. Nucleic Acids Res. 25:28-30.

Mewes, H. W., Frishman, D., Guldener, U., Mannhaupt, G., Mayer, K., Mokrejs, M., Morgenstern, B., Munsterkotter, M., Rudd, S., and Weil, B. 2002. MIPS: A database for genome and protein sequences. Nucleic Acids Res. 30:31-34.

Miao, V. P., Covert, S. F., and VanEtten, H. D. 1991. A fungal gene for antibiotic resistance on a dispensable ("B") chromosome. Science 254:1773-1776.

Namiki, F., Matsunaga, M., Okuda, M., Inoue, I., Nishi, K., Fujita, Y., and Tsuge, T. 2001. Mutation of an arginine biosynthesis gene causes reduced pathogenicity in Fusarium oxysporum f. sp. melonis. Mol. PlantMicrobe Interact. 14:580-584.

Okuno, T., Ishita, Y., Sawai, K., and Matsumoto, T. 1974. Characterization of alternariolide, a host-specific toxin produced by Alternaria mal Roberts. Chem. Lett. 1974:635-638.

Powell, W. A., and Kistler, H. C. 1990. In vitro rearrangement of foreign DNA by Fusarium oxysporum produces linear self-replicating plasmids. J. Bacteriol. 172:3163-3171.

Proctor, R. H., Brown, D. W., Plattner, R. D., and Desjardins, A. E. 2003. Co-expression of 15 contiguous genes delineates a fumonisin biosynthetic gene cluster in Gibberella moniliformis. Fungal Genet. Biol. 38:237-249.

Rosewich, U. L., and Kistler, H. C. 2000. Role of horizontal gene transfer in the evolution of fungi. Annu. Rev. Phytopathol. 38:325-363.

Rotem, J. 1994. The Genus Alternaria: Biology, Epidemiology, and Pathogenicity. The American Phytopathological Society Press, St. Paul, MN, U.S.A.

Ruswandi, S. R., Kitani, K., Akimitsu, K., Tsuge, T., Shiraishi, T., and Yamamoto, M. 2005. Structural analysis of cosmid clone pcAFT-2 carrying AFT10-1 encoding an acyl-CoA dehydrogenase involved in AFtoxin production in the strawberry pathotype of Alternaria alternata. J. Gen. Plant Pathol. 71:107-116.

Sambrook, J., and Russell, D. W. 2001. Molecular Cloning: A Laboratory Manual. 3rd ed. Cold Spring Harbor Laboratory Press, Cold Spring Harbor, NY, U.S.A.

Sawamura, K. 1990. Alternaria blotch. Pages 24-25 in: Compendium of Apple and Pear Disease. A. L. Jones, and H. Aldwinckle, eds. The American Phytopathological Society Press, St. Paul, MN, U.S.A.

Schechtman, M. G. 1990. Characterization of telomere DNA from Neurospora crassa. Gene 88:159-165.

Tanaka, A., Shiotani, H., Yamamoto, M., and Tsuge, T. 1999. Insertional mutagenesis and cloning of the genes required for biosynthesis of the host-specific AK-toxin in the Japanese pear pathotype of Alternaria alternata. Mol. Plant-Microbe Interact. 12:691-702.

Tanaka, A., and Tsuge, T. 2000. Structural and functional complexity of the genomic region controlling AK-toxin biosynthesis and pathogenicity in the Japanese pear pathotype of Alternaria alternata. Mol. PlantMicrobe Interact. 13:975-986.

Thewes, S., Prado-Cabrero, A., Prado, M. M., Tudzynski, B., and Avalos, J. 2005. Characterization of a gene in the car cluster of Fusarium fujikuroi that codes for a protein of the carotenoid oxygenase family. Mol. Genet. Genomics 274:217-228.

Thomma, B. P. H. J. 2003. Alternaria spp.: From general saprophyte to specific parasite. Mol. Plant Pathol. 4:225-236.

Thompson, J. D., Higgins, D. G., and Gibson, T. J. 1994. CLUSTAL W: Improving the sensitivity of progressive multiple sequence alignment through sequence weighting, positions-specific gap penalties and weight matrix choice. Nucleic Acids Res. 22:4673-4680.

Ueno, T., Hayashi, Y., Nakashima, T., Fukami, H., Nishimura, S., Kohmoto, K., and Sekiguchi, A. 1975. Isolation of AM-toxin I, a new phytotoxic metabolite from Alternaria mali. Phytopathology 65:82-83.

Ueno, T., Nakashima, T., Uemoto, M., Fukami, H., Lee, S. N., and Izumiya, 
N. 1977. Mass spectrometry of Alternaria mali toxins and related cyclodepsipeptides. Biomed. Mass Spectrom. 4:134-142.

VanEtten, H., Jorgensen, S., Enkerli, J., and Covert, S. F. 1998. Inducing the loss of conditionally dispensable chromosomes in Nectria haematococca during vegetative growth. Curr. Genet. 33:299-303.

Vizcaino, J. A., Sanz, L., Cardoza, R. E., Monte, E., and Gutierrez, S. 2005. Detection of putative peptide synthetase genes in Trichoderma species: Application of this method to the cloning of a gene from $T$. harzianum CECT 2413. FEMS (Fed. Eur. Microbiol. Soc.) Microbiol. Lett. 244:139-148.

Walton, J. D. 2000. Horizontal gene transfer and the evolution of secondary metabolite gene clusters in fungi: An hypothesis. Fungal Genet. Biol. 30:167-171.

Wasmann, C. C., and VanEtten, H. D. 1996. Transformation-mediated chromosome loss and disruption of a gene for pisatin demethylase decrease the virulence of Nectria haematococca. Mol. Plant-Microbe Interact. 9:793-803.

Wolpert, T. J., Dunkle, L. D., and Ciuffetti, L. M. 2002. Host-selective tox- ins and avirulence determinants: What's in a name? Annu. Rev. Phytopathol. 40:251-285.

Yamagishi, D., Akamatsu, H., Otani, H., and Kodama, M. 2006. Pathological evaluation of host-specific AAL-toxins and fumonisin mycotoxins produced by Alternaria and Fusarium species. J. Gen. Plant Pathol. 72:323-326.

Yu, J., Chang, P. K., Ehrlich, K. C., Cary, J. W., Bhatnagar, D., Cleveland, T. E., Payne, G. A., Linz, J. E., Woloshuk, C. P., and Bennett, J. W. 2004. Clustered pathway genes in aflatoxin biosynthesis. Appl. Environ. Microbiol. 70:1253-1262.

\section{AUTHOR-RECOMMENDED INTERNET RESOURCES}

NCBI BLAST website: www.ncbi.nlm.nih.gov/BLAST MIPS website: mips.gsf.de

Broad Institute website: www.broad.mit.edu DOE Joint Genome Institute website: www.jgi.doe.gov 